\title{
KANONSKO PRAVO I HRVATSKI PRAVNI SUSTAV (I). PRAVNI IZVORI I PRAVNA NAČELA
}

U posljednjih tridesetak godina, počevši od stjecanja nezavisnosti Republike $\mathrm{Hr}$ vatske i uvodenja političkog pluralizma, religija je iznova zauzela svoje odgovarajuće mjesto u javnoj sferi, pretvarajući se, metaforički rečeno, s obzirom na prethodna totalitarna iskustva, iz "društvenog neprijatelja" u "društvenog prijatelja". Navedene korjenite promjene u svijetu ideja, politike $i$ društvene prakse zahtijevale su $i$ sasvim novo uređenje odnosa prava i religije.

Uzimajući navedene činjenice kao ishodište, u ovom će se radu otpočeti raščlamba uloge i značenja unutarnjeg prava vjerskih zajednica za hrvatski pravni sustav. Pri tome ćemo se u njemu ograničiti na značenje kanonskog prava Katoličke Crkve za naš pravni sustav. Za to postoje barem dva dobra razloga. Kao prvo, brojni aspekti povijesnog i sadašnjeg fakticiteta nedvojbeno pozicioniraju Katoličku Crkvu na prednosno mjesto u hrvatskim okolnostima, počevši od činjenice da upravo njoj po vjeroispovijedi pripada daleko najveći broj hrvatskih građana. Kao drugo, istaknuto tradicijsko i aktualno značenje kanonskoga prava kao njezina pravnog poretka, doista zahtijeva posebnu i drukčiju raščlambu.

Stoga će se u nastavku rada posebna pozornost usmjeriti na problematiku kanonskog prava Katoličke Crkve kao izvora prava u hrvatskom pravnom sustavu. Nakon kratke raščlambe najvažnijih izvora kanonskog prava daljnja će analiza posebice imati za predmet značenje i funkciju načela kanonskog prava za hrvatski pravni sustav. Pri tome ćemo se posebice usredotočiti na pravne izreke (regulae iuris) kao nedvojbeno reprezentativne vrste pravnih pravila koje u velikom broju slučajeva utjelovljuju temeljna pravna načela.

Ključne riječi: kanonsko pravo, hrvatsko pravo, pravni izvori, pravna načela, regulae iuris

* Dr. sc. Marko Petrak, profesor Pravnog fakulteta Sveučilišta u Zagrebu, Trg Republike Hrvatske 14, 10000 Zagreb; marko.petrak@pravo.hr;

ORCID ID: orcid.org/0000-0003-0920-8361 


\section{UVODNE NAPOMENE**}

U posljednjih tridesetak godina, počevši od stjecanja nezavisnosti Republike Hrvatske i uvođenja političkog pluralizma, religija je iznova zauzela svoje odgovarajuće mjesto u javnoj sferi, pretvarajući se, metaforički rečeno, obzirom na prethodna totalitarna iskustva, iz "društvenog neprijatelja" u "društvenog prijatelja". Navedene korjenite promjene u svijetu ideja, politike i društvene prakse zahtijevale su i sasvim novo uređenje odnosa prava i religije. ${ }^{1}$

Počevši od Ustava Republike Hrvatske, preko četiriju međunarodnih ugovora između Svete Stolice i Republike Hrvatske, pa sve do Zakona o pravnom položaju vjerskih zajednica, postupno se izgrađivalo hrvatsko uređenje prava vjerskih zajednica koje se gotovo svakodnevno obogaćuje novim prinosima pravne prakse.

Uzimajući navedene činjenice kao ishodište, u ovom će se radu otpočeti raščlamba uloge i značenja unutarnjeg prava vjerskih zajednica za hrvatski pravni sustav. Pri tome ćemo se u njemu ograničiti na značenje kanonskog prava Katoličke Crkve za naš pravni sustav. Za to postoje barem dva dobra razloga. Kao prvo, brojni aspekti povijesnog i sadašnjeg fakticiteta nedvojbeno pozicioniraju Katoličku Crkvu na prednosno mjesto u hrvatskim okolnostima, počevši od činjenice da upravo njoj po vjeroispovijedi pripada daleko najveći broj hrvatskih građana. Kao drugo, istaknuto tradicijsko i aktualno značenje kanonskoga prava kao njezina pravnog poretka, doista zahtijeva posebnu i drukčiju raščlambu. U tom kontekstu treba već uvodno istaknuti da se međunarodni ugovori sklopljeni između Svete Stolice i Republike Hrvatske kao nadzakonski akti, a posebice Ugovor između Svete Stolice i Republike Hrvatske o pravnim pitanjima, u znatno većoj mjeri referiraju na kanonsko pravo (ius canonicum) kao pravni sustav mjerodavan za uređenje pojedinih pravnih odnosa nego što je to slučaj s tuzemnim ugovorima između Vlade Republike Hrvatske i pojedinih vjerskih zajednica. Štoviše, već u samom uvodu spomenutog ugovora navodi se i kanonsko pravo kao jedan od njegovih pravnih temelja. ${ }^{2}$ Stoga će se u nastavku rada posebna pozornost

** Rad je nastao i zahvaljujući višegodišnjim potporama Sveučilišta u Zagrebu istraživanjima pod naslovom Rimsko-kanonska pravna tradicija i europeizacija hrvatskog prava (2015-2019), kojeg je autor bio voditelj.

1 O navedenoj problematici usp. npr. Nikodem, K.; Zrinščak, S., Croatia's religious story: The coexistence of institutionalized and individual religiosity, u: Pollack, D.; Müller, O.; Pickel, G. (eds.), The social significance of religion in the enlarged Europe, Farnham/Burlington, 2012., str. 207 - 227; Jakulj, I., Pravni položaj Katoličke Crkve u Republici Hrvatskoj: od totalitarizma do demokracije, Crkva u svijetu, vol. 50, br. 3, 2015., str. 478 - 513.

2 Tekst relevantnog dijela uvoda Ugovora između Svete Stolice i Republike Hrvatske o pravnim pitanjima glasi: "Sveta Stolica i Republika Hrvatska, nastojeći odrediti pravni 
usmjeriti na problematiku kanonskog prava Katoličke Crkve kao izvora prava u hrvatskom pravnom sustavu, s posebnim težištem na značenje pravnih načela kanonskog prava u hrvatskom kontekstu.

\section{KANONSKO PRAVO I CIVILNO PRAVO}

Razmatrajući međusobni odnos kanonskog prava Katoličke Crkve i pravnog sustava Republike Hrvatske, ponajprije je potrebno razjasniti jedno terminološko pitanje, potaknuto već samim tekstovima četiriju međunarodnih ugovora između Svete Stolice i Republike Hrvatske (Ugovor izmedu Svete Stolice i Republike Hrvatske o pravnim pitanjima; Ugovor izmedu Svete Stolice i Republike Hrvatske o suradnji na području odgoja i kulture; Ugovor između Svete Stolice i Republike Hrvatske o dušobrižništvu katoličkih vjernika, pripadnika oružanih snaga i redarstvenih službi Republike Hrvatske; Ugovor između Svete Stolice i Republike Hrvatske o gospodarskim pitanjima). ${ }^{3}$ Tekstovi navedenih ugovora s jedne strane govore o "kanonskom pravu", "crkvenom zakonodavstvu", "crkvenim zakonima"6 ili "crkvenim

okvir odnosa između Katoličke Crkve i Hrvatske Države, temeljeći se Republika Hrvatska na odredbama Ustava, posebno na člancima 40. i 41. o vjerskoj slobodi i o slobodi savjesti, a Sveta Stolica na dokumentima Drugoga vatikanskog sabora i na odredbama kanonskoga prava ... dogovorili su se o slijedećem..."; vrlo slične formulacije o kanonskom pravu kao jednom od temelja ugovora nalaze se i u uvodu Ugovora izmedu Svete Stolice i Republike Hrvatske o suradnji na području odgoja i kulture te Ugovora između Svete Stolice i Republike Hrvatske o gospodarskim pitanjima; o značenju kanonskog prava kao temelja navedenih međunarodnih ugovora vidi ukratko Eterović, N., Ugovori između Svete Stolice i Republike Hrvatske (povijest nastanka i komentar), Zagreb, 2001., str. 136 - 137.

3 Detaljno o nastanku, sadržaju i značenju navedenih međunarodnih ugovora između Svete Stolice i Republike Hrvatske u komparativnom kontekstu vidi u: Eterović, N., op. cit. u bilj. 2, str. $1-402$.

4 Ugovor između Svete Stolice i Republike Hrvatske o pravnim pitanjima, čl. 2. st. 2.3.; čl. 6. st. 1.; čl. 10. st. 1.; usp. Ugovor između Svete Stolice i Republike Hrvatske o gospodarskim pitanjima, čl. 1. st. 1.; Ugovor između Svete Stolice i Republike Hrvatske o dušobrižništvu katoličkih vjernika, pripadnika oružanih snaga i redarstvenih službi Republike Hrvatske, čl. 1. st. 2.; čl. 3.; čl. 4. st. 2.; čl. 5.; čl. 6. st. 2.; Ugovor između Svete Stolice i Republike Hrvatske o suradnji na području odgoja i kulture, čl. 8. st. 1.; čl. 11. st. 1.

5 Ugovor između Svete Stolice i Republike Hrvatske o suradnji na području odgoja i kulture, čl. 7. st. 1 .

6 Ugovor između Svete Stolice i Republike Hrvatske o suradnji na području odgoja i kulture, čl. 7. st. 2.; čl. 12. st. 2. 
propisima"”, odnosno pojedinim institutima kanonskog prava ("kanonska ženidba" " "kanonske kaznene mjere"9 "kanonski mandat"10). S druge je strane riječ o "zakonodavstvu Republike Hrvatske", "zakonskim odredbama”, "zakonima Republike Hrvatske"11, "državnom zakonodavstvu"12 ili "državnim propisima”"13, odnosno pojedinim aspektima državnog prava (npr. "građanski učinci” ${ }^{4}$, "građanska prava i obveze"15, "civilne zapreke"16).

Bez obzira na navedene varijacije $\mathrm{u}$ terminologiji navedenih ugovora, nesporno je da je riječ o izrazima koji označavaju dva zasebna i različita pravna sustava: kanonsko pravo (ius canonicum) s jedne strane i civilno pravo (ius civile) s druge strane. Premda je u antičkom Rimu izraz ius civile izvorno označavao dio rimskog pravnog sustava koji je po načelu personaliteta vrijedio isključivo za rimske građane (cives Romani), za razliku od ius gentium kao dijela rimskog pravnog sustava koji je vrijedio i za rimske građane i za strance (peregrini), od srednjeg vijeka pa sve do danas termin ius civile označava sustav svjetovnog prava, utemeljen na Justinijanovoj kodifikaciji rimskog prava (Corpus Iuris Civilis), za razliku od termina ius canonicum, koji označava sustav kanonskog prava (Corpus Iuris Canonici). Kako vidimo, na navedeno razlikovanje između civilnog prava kao svjetovnog pravnog poretka te kanonskog prava kao pravnog sustava Katoličke Crkve nailazimo i u međunarodnim ugovorima između Svete Stolice i Repub-

7 Ugovor između Svete Stolice i Republike Hrvatske o gospodarskim pitanjima, čl. 8. st. 2.

8 Ugovor između Svete Stolice i Republike Hrvatske o pravnim pitanjima, čl. 13.

9 Ugovor između Svete Stolice i Republike Hrvatske o dušobrižništvu katoličkih vjernika, pripadnika oružanih snaga i redarstvenih službi Republike Hrvatske, čl. 6. st. 3.

10 Ugovor izmedu Svete Stolice i Republike Hrvatske o suradnji na području odgoja i kulture, čl. 3. st. 2 .

11 Ugovor između Svete Stolice i Republike Hrvatske o pravnim pitanjima, čl. 10.; čl. 11. st. 1.; čl. 12. st. 2.; čl. 13.; čl. 14. st. 1.; čl. 15.; čl. 17. st. 5.; Ugovor između Svete Stolice i Republike Hrvatske o gospodarskim pitanjima, čl. 2. st. 1.; čl. 3. st. 1.; čl. 4. st. 1.; čl. 5. st. 2.; čl. 6. st. 1.; čl. 7. st. 2.; Ugovor između Svete Stolice i Republike Hrvatske o suradnji na području odgoja i kulture, čl. 3. st. 1.; čl. 7.; čl. 8.; čl. 9.; čl. 10. st. 1.; čl. 11. st. 1. i 2.; čl. 12. st. 2.

12 Ugovor između Svete Stolice i Republike Hrvatske o suradnji na području odgoja i kulture, čl. 7. st. 1.

13 Ugovor izmedu Svete Stolice i Republike Hrvatske o pravnim pitanjima, čl. 2. st. 3.; Ugovor između Svete Stolice i Republike Hrvatske o gospodarskim pitanjima, čl. 8. st. 2.

14 Ugovor između Svete Stolice i Republike Hrvatske o pravnim pitanjima, čl. 10. st. 2.; čl. 13.; čl. 14. st. 1.; čl. 17. st. 5.

15 Ugovor između Svete Stolice i Republike Hrvatske o gospodarskim pitanjima, čl. 8. st. 2.

16 Ugovor između Svete Stolice i Republike Hrvatske o pravnim pitanjima, čl. 13. st. 1. 
like Hrvatske. Zaključujući ove kratke terminološke napomene, istaknimo da smatramo da bi u navedenom kontekstu bilo bolje koristiti izraz "civilno pravo" umjesto izraza "građansko pravo" kao oznaku za sustav svjetovnog ili državnog prava. Time bi se umanjila mogućnost zbunjujuće dvoznačnosti s obzirom na to da se izraz "građansko pravo" u hrvatskom pravnom jeziku gotovo isključivo koristi u smislu općeg privatnog prava kao središnje, ali ipak pojedinačne pravne grane u suvremenim kontinentalnim europskim pravnim sustavima. ${ }^{17}$

Bez obzira na navedenu zasebnost i različitost kanonskog prava s jedne strane te civilnog prava s druge strane, navedena dva pravna sustava međusobno se mogu prožimati i ispreplitati na različite načine. Tako, primjerice, kanonsko pravo preuzima u pogledu određenih pravnih materija važeće civilne zakone u kanonskopravni poredak. Kako je opće poznato u kanonističkoj znanosti, riječ je o načinu normiranja koji se naziva "kanonizacija civilnih zakona" (canonizatio legum civilium). Pretpostavke i granice kanonizacije civilnih zakona preciznije definira Zakonik kanonskog prava (Codex Iuris Canonici) iz 1983. (dalje u tekstu: CIC), kan. 22., koji određuje da se "civilni (svjetovni) zakoni, na koje upućuje crkveno pravo ... u kanonskom pravu obdržavaju s jednakim učincima, ako nisu protivni božanskom pravu i ako kanonsko pravo ne određuje nešto drugo". ${ }^{18}$ Možda se najpoznatiji takav primjer "kanonizacije civilnih zakona" nalazi u CIC-u, kan. 1290., koji pod određenim uvjetima predviđa kanonizaciju svjetovnog ugovornog prava određene države: "Ono što civilno pravo na nekom području određuje o ugovorima, bilo općenito bilo posebno, i o njihovu ispunjenju, neka se s istim učincima obdržava u kanonskom pravu u stvarima koje podliježu crkvenoj vlasti upravljanja, osim ako se to protivi božanskom pravu ili ako nešto drugo određuje kanonsko pravo..."19

17 Usp. npr. Klarić, P.; Vedriš, M., Građansko pravo, Zagreb, 2006., str. 5 - 6; Škalabrin, N., Uvod u kanonsko pravo, Đakovo, 1994., str. 94.

18 Can. 22: Leges civiles ad quas ius Ecclesiae remittit, in iure canonico iisdem cum effectibus serventur, quatenus iuri divino non sint contrariae et nisi aliud iure canonico caveatur; općenito o kanonizaciji civilnih zakona vidi npr. Brkan, J., Opće odredbe Zakonika kanonskog prava, Makarska, 1997., str. 82 - 83; Škalabrin, N., Ugovori i napose otuđenje (kann. 1290-1298), Bogoslovska smotra, vol. 76, br. 1, 2006., str. 174 - 177, s uputama na daljnju inozemnu literaturu.

19 Can. 1290: Quae ius civile in territorio statuit de contractibus tam in genere, quam in specie et de solutionibus, eadem iure canonico quoad res potestati regiminis Ecclesiae subiectas iisdem cum effectibus serventur, nisi iuri divino contraria sint aut aliud iure canonico caveatur, et firmo iure canonico caveatur...; o navedenom kanonu kojim se kanonizira svjetovno ugovorno pravo vidi detaljnije u: Brkan, J., Ugovori i napose otudenje (kan. 1290-1298), Služba Božja, vol. 45, br. 2, 2004., str. 12 - 16; Škalabrin, N., op. cit. u bilj. 18, str. 173 - 177. 
Za razliku od kanonizacije civilnih zakona, drugi mogući način međusobnog prožimanja i ispreplitanja kanonskog prava i civilnog prava jest prihvaćanje kanonskog prava kao izvora važećeg civilnog prava glede određenih pravnih materija. Navedeni fenomen "civilifikacije" kanonskog prava dobio je odavno svoj latinski naziv: ius canonicum in iure civili ("kanonsko pravo u civilnom pravu"). ${ }^{20}$ Usredotočujući se u nastavku rada na problematiku uloge kanonskog prava kao izvora prava u hrvatskom civilnopravnom sustavu, posebice ćemo raščlaniti tradicijsko i aktualno značenje načela kanonskog prava za naše civilno pravo.

\section{IZVORI KANONSKOG PRAVA}

Prije same raščlambe uloge i značenja načela kanonskog prava u hrvatskom kontekstu, potrebno je - radi boljeg i sveobuhvatnijeg razumijevanja problematike - istaknuti na doista koncizan način nekoliko činjenica o najvažnijim današnjim izvorima kanonskog prava, relevantnim u kontekstu hrvatskog pravnog sustava.

Kako smo već istaknuli, međunarodni ugovori sklopljeni između Svete Stolice i Republike Hrvatske u znatnoj se mjeri referiraju na kanonsko pravo kao pravni sustav mjerodavan za uređenje pojedinih pravnih odnosa. Cjelina navedenih međunarodnih ugovora između Svete Stolice i Republike Hrvatske tvori zasebnu pravnu granu u kontekstu hrvatskog pravnog sustava: konkordatsko pravo (ius concordatarium). Kako je već istaknuto u doktrini, "to je pravo redovito nepoznato drugim Crkvama i vjerskim zajednicama, iako i one mogu sklopiti slične sporazume s državnim vlastima koji međutim nemaju međunarodno obilježje” ${ }^{21}$ Još detaljnije rečeno, "ugovori predstavljaju izraz usklađivanja dvaju pravnih sustava, crkvenoga i državnoga, a spadaju u konkordatsko pravo koje je plod dugoga i posebnoga povijesnog nastojanja i iskustva odnosa Katoličke Crkve s državama i njezine prisutnosti u različitim narodima svijeta. Ugovori nadalje daju hrvatskom pravu novi doprinos i otvaraju novo područje suradnje između kanonskoga i građanskoga prava." 22

20 O navedenoj problematici vidi detaljnije npr. u: Wolter, U., Ius canonicum in iure civili. Studien zur Rechtsquellenlehre in der neueren Privatrechtsgeschichte, Köln/Wien, 1975.

21 Cit. Eterović, N., Ugovori između Svete Stolice i Republike Hrvatske, Crkva u svijetu, vol. 32, br. 2, 1997., str. 184.

22 Cit. Bozanić, J., Predgovor, u: Eterović, N., Ugovori između Svete Stolice i Republike Hrvatske (povijest nastanka i komentar), op. cit. u bilj. 2, str. 6; usp. i Zec, S., Pravni temelji prisutnosti $i$ djelovanja Crkve u javnosti u Republici Hrvatskoj, Riječki teološki časopis, vol. 36, br. 2, 2011 ., str. $397-399$. 
U ovom radu nećemo se posebno baviti iznimno važnom problematikom odredbi kanonskog prava kao pravnog izvora u hrvatskom pravnom sustavu temeljem konkordatskog prava, već navedenu raščlambu ostavljamo za prvu sljedeću prigodu. Međutim, imajući u vidu, kako je već istaknuto, da su upravo "odredbe kanonskog prava" explicite navedene kao jedan od samih fundamenata međunarodnih ugovora između Svete Stolice i Republike Hrvatske, potrebno je ipak ovdje utvrditi na koje se pravne izvore spomenuta sintagma "odredbe kanonskog prava" točno odnosi. U tom kontekstu dostatno je navesti da je u doktrini već precizno i jezgrovito istaknuto da se u uvodima tih međunarodnih ugovora "izrazom odredbe kanonskog prava podrazumijevaju odredbe Zakonika kanonskog prava i Zakonika kanona istočnih crkava te sve druge odredbe Katoličke Crkve koje imaju snagu zakona, bilo opće, koje vrijede za cijelu Katoličku Crkvu, bilo posebne, kao na primjer, odredbe Hrvatske biskupske konferencije koje vrijede za Katoličku Crkvu u Republici Hrvatskoj”. ${ }^{23}$

Kako bismo ukratko razjasnili navedeni uvid, potrebno je istaknuti da na području Republike Hrvatske, osim izrazito većinske Crkve latinskog obreda, koja obuhvaća više od 99 \% katolika u Hrvatskoj (i oko 98,6 \% od oko milijardu i tristo milijuna katolika u svijetu), postoji i grkokatolička Križevačka eparhija, koja ima status samosvojne Crkve (sui iuris) bizantsko-slavenskog obreda nasta$\log$ iz carigradske predaje (traditio Constantinopolitana). ${ }^{24}$ Sukladno navedenim činjenicama, daleko najvažniji izvor kanonskog prava u hrvatskom kontekstu jest Zakonik kanonskog prava (Codex Iuris Canonici) iz 1983. (CIC) kao zakonik latinske Crkve, nedvojbeno najvažnija religijska pravna kodifikacija u svjetskim razmjerima. Međutim, u Križevačkoj eparhiji primjenjuje se druga velika kodifikacija kanonskog prava u Katoličkoj Crkvi: Zakonik kanona istočnih Crkava (Codex Canonum Ecclesiarum Orientalium) iz 1990. (dalje u tekstu: CCEO) kao zakonik istočnih katoličkih crkava, pripadnim obredima (ritus) aleksandrijske, antiohijske, armenske, kaldejske i carigradske predaje. Oba ta velika zakonika kanonskog prava, proglašena u doba pontifikata sv. Ivana Pavla II., izdana su i u Hrvatskoj u svojim izvornicima na latinskom jeziku uz usporedni hrvatski prijevod. ${ }^{25} \mathrm{O}$ istovjetnostima i razlikama između tih dvaju kanonskih zakonika u hrvatskom kontekstu već je pisano u našoj kanonističkoj znanosti te stoga

23 Cit. Eterović, N., op. cit. u bilj. 2, str. 137.

24 O povijesti Križevačke eparhije vidi npr. Ivanišević, G., Marčanska unija 1611. i Križevačka eparhija 1777. Ljetopis i pojmovnik, Zagreb, 2018., uz iscrpnu bibliografiju.

25 Codex Iuris Canonici fontium annotatione auctus/Zakonik kanonskog prava s izvorima, Zagreb, 1996; Codex Canonum Ecclesiarum Orientalium fontium annotatione auctus/Zakonik kanona istočnih Crkava s izvorima, Zagreb, 1996. 
upućujemo na ta vrijedna istraživanja ${ }^{26}$, a također treba istaknuti i da je objavljen Usporedni popis kanona CIC i CCEO uz pomoć kojega je moguće na jednostavan način pronaći podudarne i usporedive kanone dvaju zakonika. ${ }^{27}$

U navedenom kontekstu potrebno je istaknuti i jednu posebnost izvora kanonskog prava, posebice u usporedbi s modernim ili današnjim svjetovnim pravom. Naime, za razliku od svjetovnog prava, u kojem se donošenjem novog zakonodavstva, osobito od strane revolucionarnog ili radikalnije reformističkog zakonodavca, često stvara temeljiti diskontinuitet između starog i novog prava, tj. pravne tradicije i sadašnjosti, određene formalno nove odredbe kanonskog prava vrlo često će predstavljati izravan ishod organskog razvoja dotadašnjeg uređenja u trajnom povijesnom kontinuitetu. To shvaćanje izravno normira i CIC u svojem kan. 6, § 2, ističući sljedeće: "Kanoni ovoga Zakonika, ako preuzimaju staro pravo, treba da se prosuđuju uzimajući u obzir i kanonsku predaju". ${ }^{28}$ Kako vidimo, odredbe starog prava (ius vetus), koje su preuzete u CIC, a takvih je mnoštvo, trebaju se tumačiti sukladno kanonskoj predaji (traditio canonica). ${ }^{29}$ Kanonska predaja kao normativna koncepcija tu ne bi samo označavala neposredno prethodni Zakonik kanonskog prava (Codex Iuris Canonici) iz 1917. (dalje u tekstu: CIC 1917) - inače također nedavno objavljen u nas na latinskom jeziku uz usporedni hrvatski prijevod - te na njemu utemeljenu doktrinu i praksu. ${ }^{30}$ Ta normativna koncepcija po svojoj naravi zapravo predstavlja svekoliku tisućljetnu kanonsku tradiciju, počev od njezine prve velike sistematizacije u latinskoj Crkvi, znamenitog Gracijanova dekreta (Decretum Gratiani), nastalog u Bologni oko 1140., preko zbirke Dekretali (Decretales) pape Grgura IX. (1234.), Liber sextus pape Bonifacija VIII. (1298.), Constitutiones Clementinae pape Klementa V. (1317.), Extravagantes pape Ivana XXII. (1325.) ili Extravagantes communes (1500.),

26 Brkan, J., Neke razlike u Zakonicima latinske Crkve i istočnih katoličkih crkava, Služba Božja, vol. 54, br. 1, 2014., str. 5 - 34 .

27 Navedeni Usporedni popis kanona CIC i CCEO priredio je Matija Berljak, dugogodišnji predstojnik Katedre kanonskog prava Katoličkog bogoslovnog Fakulteta Sveučilišta u Zagrebu, a objavljen je u: Codex Iuris Canonici fontium..., op. cit. u bilj. 25, str. $1086-1121$.

28 Can. 6, § 2: Canones huius Codicis, quatenus ius vetus referunt, aestimandi sunt ratione etiam canonicae traditionis habita.

29 Brkan, J., Opće odredbe..., op. cit. u bilj. 18, str. 25 - 26.

30 Codex Iuris Canonici iz 1917. nedavno je izdan u Hrvatskoj čak u dvama prijevodima, izrađenima još u prvoj polovici 20. st. (Josip Pazman, Franjo Herman), koji prethodno nisu objavljeni; Codex Iuris Canonici fontium annotatione auctus MDCCCCXVII/ Kodeks kanonskog prava s izvorima 1917. (preveo Franjo Herman), Zagreb, 2007.; Berljak, M., Zakonik crkvenog prava, uređen po odredbi pape Pija X., proglašen po nalogu pape Benedikta XV. (1917.). Dr. Josip Pazman (1863.-1925.), Zagreb/Rim, 2014. 
pa sve do autentičnog izdanja i autoritativnog oblika svih tih zbirki u sintezi pod nazivom Corpus iuris canonici, koju je nakon Tridentskog sabora odobrio i naredio izdati papa Grgur XIII. (1580.), a ostala je temeljni i najznačajniji izvor kanonskog prava sve do CIC-a iz 1917. ${ }^{31}$ Kako je također u nas objavljen i Usporedni popis kanona CIC-a iz 1983. i CIC-a iz 1917. ${ }^{32}$, a hrvatsko izdanje CIC-a iz 1917. sadržava u bilješkama slijed izvora za kanone koji u određenim slučajevima seže unatrag sve do Gracijanova dekreta (jednako kao što izdanje CCEO sadržava takve izvore unazad sve do ekumenskih koncila prvog tisućljeća i Justinijanove kodifikacije ${ }^{33}$ ), traditio canonica doista se može u slučaju svake pojedinačne odredbe tekstualno i kontekstualno pratiti sve do samog izvorišta.

U okvirima navedene tradicije posebno značenje imaju regule kanonskog prava (regulae iuris canonici) u značenju općih pravnih načela. Takve regulae, ako u sebi sadržavaju opća pravna načela (generalia iuris principia) kao temelj čitavog sustava kanonskog prava, predstavljaju i u formalnom smislu, sukladno CIC-u (kan. 19), jedan od izvora tzv. dopunskog prava (ius suppletorium) kao sredstva za popunjavanje pravnih praznina. $U$ tom smislu napose je znamenito 99 srednjovjekovnih regula, od kojih je prvih 11 regula preuzeto iz Dekretala pape Grgura IX., a ostalih 88 regula iz Liber Sextus pape Bonifacija VIII. ${ }^{34}$ Kako ćemo

31 Povijesnu sintezu izvora kanonskog prava pružio je na hrvatskom jeziku u novije vrijeme Škalabrin, N., Uvod u kanonsko pravo, op. cit. u bilj. 17, str. 87 - 105; usp. i Rogić, I., Kanonsko pravo I. Prva knjiga Kodeksa. Opća pravila (Normae generales), Đakovo, 1939., str. 19 - 41. Od stranih djela upućujemo ovdje samo na fascinantnu sintezu Gaudemet, J., Les sources du droit canonique (VIII ${ }^{e}-X X^{e}$ siècle), Paris, 1993.; o pojmu kanonske predaje (traditio canonica) usp. Pree, H., Traditio Canonica. The Norm of Interpretation of Canon $6 \mathrm{sec} .2$ of the C.I.C., Ius Canonicum, vol. 35, 1995., str. 423 - 446.

32 Navedeni Usporedni popis kanona CIC-a iz 1983. i CIC-a iz 1917. priredio je također Matija Berljak, a objavljen je u Codex Iuris Canonici fontium..., op. cit. u bilj. 25, str. $1122-1162$.

33 O rimsko-bizantskim pravnim izvorima u CCEO-u vidi npr. Ceccarelli Morolli, D., "Fragmenta Iuris Romani-Byzantini" nel Codex Canonum Ecclesiarum Orientalium: note per un primo studio, Iura Orientalia, vol. 1, 2005., str. 77 - 87.

34 Decretal. Gregor. IX. lib. V. tit. XLI, de regulis iuris, c. 1-11.; Sexti decretal. lib. V. tit. XIII. de regulis iuris. Bonifacius VIII, regulae 1-88; općenito o regulama kanonskog prava koje sadržavaju opća pravna načela kao supsidijarnom izvoru kanonskog prava vidi Brkan, J., Opće odredbe, op. cit. u bilj. 18, str. 74 - 75, posebice bilj. 41.; usp. i Pree, H., Generalia Iuris Principia im CIC/1983 und Ihre Bedeutung für das Kanonische Recht, Archiv für katholisches Kirchenrecht, vol. 172, br. 1, 2003., str. 38 - 57; Rehak, M., Regulae iuris und allgemeine Rechtsprinzipien im kanonischen Recht, u: Schüller, T., Neumann, T. (ur.), Kirchenrecht im Dialog. Tagungsband zur Tagung des Instituts für kanonisches Recht, Fulda, 18.-20. Februar 2019, Berlin, 2020., str. 43 - 72, s uputama na brojnu daljnju literaturu. 
vidjeti u nastavku rada, navedenih 99 regula ima i napose relevantno značenje u specifičnom hrvatskom kontekstu. ${ }^{35}$

Sve u svemu, valja zaključiti da se važeći izvori kanonskog prava ne mogu nipošto ograničiti na najnovije zakonodavstvo. Obuhvaćajući svekoliku kanonsku predaju, ti su izvori, parafrazirajući riječi Sv. Pisma, poput riznice (thesaurus) iz koje se iznosi novo i staro (nova et vetera). ${ }^{36}$

\section{IUS CANONICUM IN IURE CIVILI: NAČELA KANONSKOG PRAVA I HRVATSKI PRAVNI SUSTAV}

Nakon kratke raščlambe izvora kanonskog prava, kako smo već naprijed istaknuli, daljnja će analiza posebice imati za predmet značenje i funkciju načela kanonskog prava za civilno pravo u hrvatskom kontekstu. Pri tome ćemo se posebice usredotočiti na pravne izreke (regulae iuris) kao nedvojbeno reprezentativne vrste pravnih pravila koje u velikom broju slučajeva utjelovljuju temeljna pravna načela. Te pravne izreke - postojeće već u izvorima antičkog rimskog prava te preuzete $\mathrm{u}$ potonjim razdobljima u kanonsko pravo ili pak izvorno formulirane u srednjovjekovnoj i novovjekovnoj kanonskoj pravnoj tradiciji na temelju pravnih pravila sadržanih u Corpus iuris civilis ili Corpus iuris canonici - posebice su važne iz razloga što je u njima na krajnje sažet i jezgrovit način sabrano tisućljetno europsko pravničko iskustvo. Stoga je njihov sadržaj u velikoj mjeri ugrađen u suvremene pravne sustave, pa tako i hrvatski, a pravna praksa i pravna doktrina i danas ih često citiraju na latinskom jeziku kao privilegirane iskaze neprolaznih pravnih istina. ${ }^{37}$

U nastavku ćemo ponajprije raščlaniti pitanje u kojoj su mjeri načela kanonskog prava i danas "nosivi stupovi" pojedinih temeljnih instituta u hrvatskom civilnopravnom sustavu. Potom ćemo nastojati otići i korak dalje te pokušati odgovoriti na pitanje mogu li se regulae iuris canonici kao načela kanonskog prava izravno primijeniti u suvremenom hrvatskom pravu kao pravni izvor?

35 Vidi infra pod 4.2.

36 Evanđelje po Mateju, 13, 52.

37 O značenju latinskih pravnih izreka kao jednog od temeljnih elemenata europske pravne tradicije i kulture vidi npr. Wacke, A., Sprichwörtliche Rechtsprinzipien und europäische Rechtsangleichung, Orbis iuris romani, vol. 5, 1999., str. 174 - 213; usp. i Liebs, D., Lateinische Rechtsregeln und Rechtssprichwörter, München, 1991., str. 9 - 14; Kranjc, J., Latinski pravni reki, Ljubljana, 1998., str. 5 - 8; Domingo, R. et al., Principios de derecho global. 1000 reglas y aforismos jurídicos comentados, Navarra, 2006., str. 23 - 29; Petrak, M., Traditio iuridica, vol. I: Regulae iuris, Zagreb, 2010., str. 9 - 12 (dalje cit. Petrak, M., Traditio). 


\subsection{Načela kanonskog prava u civilnom pravu}

Kako smo istaknuli, u nastavku ćemo raščlambu otpočeti s problematikom prisutnosti tradicionalnih načela kanonskog prava kao temelja iznimno važnih segmenata današnjeg hrvatskog civilnog prava. Pri tome ćemo se doista zadržati na reprezentativnim primjerima.

U sferi obiteljskog prava, primjerice, treba istaknuti izreku matrimonia debent esse libera (lat. "brakovi moraju biti slobodni”) koja sadržava temeljno obiteljskopravno načelo slobode sklapanja brakova u smislu da bračni pristanak mora biti slobodan. Načelo sadržano u navedenoj izreci, nastaloj na temelju jedne konstitucije cara Aleksandra Severa (3. st.) te prenesenoj u Codex Iustinianus 8, 38, 2, u potpunosti je afirmirano u razdoblju klasičnog rimskog prava. Tako, primjerice, iz zaruka (sponsalia) ne proizlazi utuživa obveza na sklapanje braka te je ujedno nevaljana svaka klauzula kojom bi se zaručnici obvezivali platiti ugovornu kaznu za slučaj da se ne sklopi brak (vidi npr. Paul. Digesta 45, 1, 134 pr.). Međutim, u potonjim razdobljima postklasičnog rimskog prava te srednjovjekovnog rimsko-bizantskog prava, kao i u germanskim pravima, prevladalo je shvaćanje da iz zaruka proizlazi pravna obveza na sklapanje braka. Međutim, navedeno klasično rimsko načelo očuvalo se u tradiciji kanonskog prava te je u potpunosti reafirmirano njegovom prvom kodifikacijom (vidi npr. CIC 1917, kan. 1017, § 3), a istoznačnu odredbu sadržava i današnji CIC (kan. 1062, § 2): Ex matrimonii promissione non datur actio ad petendam matrimonii celebrationem ("iz obećanja ženidbe ne stječe se pravo na tužbu za sklapanje ženidbe”). Klasično načelo slobode sklapanja braka u potpunosti je ugrađeno i u suvremene pravne sustave: "institut zaruka kao običaj vrlo je rasprostranjen i primjenjuje se na razne načine i danas u gotovo svim civiliziranim zemljama, a gotovo sva se europska zakonodavstva pridržavaju rimskog načela matrimonia debent esse libera" ${ }^{38}$

Iz područja ugovornog prava istaknut ćemo izreku pacta sunt servanda (lat. “sporazume treba poštovati”): fundamentalno načelo obveznoga prava koje određuje da ugovore treba izvršavati onako kako je ugovoreno. Prema tom načelu ugovor za stranke ima snagu zakona (contractus contrahentibus lex esto): one

38 Cit. Majstorović, I., Zaruke i miraz kao neregulirani instituti suvremenog hrvatskog obiteljskog prava, Zbornik Pravnog fakulteta u Zagrebu, vol. 55, br. 3-4, 2005., str. 761; općenito o navedenoj problematici usp. Milotić, I., Zaruke u europskoj pravnoj tradiciji do XIX. stoljeća i njihovo uređenje na hrvatskom pravnom prostoru, u: Šalković, J. (ur.), Zaručništvo i priprava za ženidbu, Zagreb, 2015., str. 47 - 74; Petrak, M., »In nostro territorio matrimonii promissio (sponsalia) sensu iuridico non amplius dantur«? Kratke napomene o kanonskom uređenju zaruka u Hrvatskoj (Kan. 1062), u: Šalković, J. (ur.), Zaručništvo i priprava za ženidbu, Zagreb, 2015., str. 31 - 45. 
ga moraju poštovati i izvršavati jednako kao i zakon. ${ }^{39}$ Drugim riječima, načelo pacta sunt servanda određuje da subjekti koji su sklopili određeni ugovor ne mogu od njega jednostrano odustati bez štetnih posljedica za sebe. Povrh toga, navedeno načelo onemogućuje svojevoljno mijenjanje sadržaja ili načina izvršenja ugovora. Prve začetke načela pacta sunt servanda - kako je moguće zaključiti na temelju jednog fragmenta slavnog klasičnog rimskog pravnika Ulpijana (Ulpianus) (Digesta 2, 14, 7,7) - nalazimo već u obećanju rimskog pretora da će zahtijevati poštovanje sporazuma ugovornih strana (pacta conventa servabo!). ${ }^{40}$ Polazeći od navedenih antičkih rimskih temelja, izreka pacta sunt servanda uzdignuta je na razinu fundamentalnog obveznopravnog načela u srednjovjekovnom kanonskom pravu, o čemu nam svjedoči jedna odredba (X. 1, 35, l) iz Dekretala (Decretales) pape Grgura IX. ${ }^{41}$ Posredstvom tradicije rimsko-kanonskog općeg prava (ius commune) navedeno je načelo ugrađeno u temelje suvremenih europskih obveznopravnih sustava. U hrvatskom pravu, primjerice, sukladno čl. 9. Zakona o obveznim odnosima, načelo pacta sunt servanda pod nazivom "dužnost ispunjenja obveze" predstavlja jedno od osnovnih načela obveznog prava koje određuje da je sudionik u obveznom odnosu dužan ispuniti svoju obvezu te je odgovoran za njezino ispunjenje. Također, u međunarodnom javnom pravu, Bečka konvencija o pravu međunarodnih ugovora iz 1969., kao temeljni propis koji na globalnoj razini regulira navedenu materiju, određuje u svojem čl. 26. - i to izravno na latinskom jeziku - da je načelo pacta sunt servanda fundamentalno načelo prava međunarodnih ugovora. Stoga se izreka pacta sunt servanda često koristi i u suvremenoj građanskopravnoj doktrini te međunarodnopravnoj doktrini u

39 O reguli contractus contrahentibus lex esto vidi Petrak, M., Traditio, op. cit. u bilj. 37, str. $42-43$.

40 Ulp. D. 2, 14, 7, 7: Ait pretor: 'Pacta conventa, quae neque dolo malo, neque adversus leges plebis scita senatus consulta decreta edicta principium, neque quo fraus cui eorum fiat, facta erunt, servabo' ('Pretor kaže: 'Pakte koji budu sklopljeni bez zle namjere, a nisu suprotni zakonima, plebiscitima, senatskim mišljenjima te dekretima i ediktima careva, niti je u njima sadržana prijevara, nakon što budu sklopljeni, zaštitit ću'”); o značenju navedenog izvora vidi npr. u: Archi, G. G., “Ait Praetor: 'Pacta conventa servabo", u: Harder, M.; Thielmann, G. (eds.), De iustitia et iure. Festgabe für Ulrich von Lübtow zum 80. Geburtstag, Berlin, 1980., str. 373 - 403, s uputama na daljnju literaturu.

${ }^{41}$ O oblikovanju načela pacta sunt servanda u srednjovjekovnom kanonskom pravu i njegovu značenju u suvremenom ugovornom pravu vidi npr. u: Landau, P., Pacta sunt servanda. $\mathrm{Zu}$ den kanonistischen Grundlagen der Privatautonomie, u: Ascheri, M. et al., "Ins Wasser geworfen und Ozeane durchquert". Festschrift für Knut Wolfgang Nörr, Köln/Weimar/Wien, 2003., str. 457 - 474; usp. i Zimmermann, R., The Law of Obligations, Roman Foundations of the Civilian Tradition, Oxford, 1996., str. 542 - 582. 
opisanom značenju temeljnog obveznopravnog načela. ${ }^{42}$ Povrh toga, navedena se izreka izravno na latinskom jeziku često primjenjuje kao nadasve relevantan normativni sadržaj i u suvremenoj hrvatskoj sudskoj praksi, primjerice Vrhovnog suda Republike Hrvatske. ${ }^{43}$ Kako vidimo, i u ovom je slučaju kanonsko pravo na presudan način utjecalo na suvremene pravne sustave. ${ }^{44}$

Iz područja kaznenog prava u navedenom kontekstu neka bude istaknuta izreka nulla poena sine culpa (lat. "nema kazne bez krivnje”), kojom se izražava načelo krivnje u kaznenom pravu. Tim se načelom isključuje svaki oblik kažnjavanja koji bi se zasnivao na objektivnoj odgovornosti. Navedeni je koncept prvi put formuliran u obliku izreke $\mathrm{u}$ jednom fragmentu klasičnog pravnika Ulpijana (Ulpianus), koji glasi: poena sine fraude esse non potest (lat. "ne može biti kazne bez krivnje") (Digesta 50, 16, 131, 1). Spomenuti je antički fragment uzdignut na razinu načela upravo u srednjovjekovnom kanonskom pravu. Tako pravna zbirka Liber Sextus $(5,13,23)$ pape Bonifacija VIII. sadržava sljedeću odredbu: sine culpa, nisi subsit causa, non est aliquis puniendus (lat. "bez krivnje, osim ako ne postoji poseban razlog, nitko ne može biti kažnjen”). Posredstvom rimsko-kanonske pravne tradicije izreka nulla poena sine culpa kao jezgrovita formulacija načela krivnje ugrađena je u brojne suvremene kaznenopravne sustave. Tako, primjerice, u hrvatskom pravnom sustavu navedeno kaznenopravno načelo sadržano je u čl. 4. hrvatskog Kaznenog zakona, koji određuje da "nitko ne može biti kažnjen ako nije kriv za počinjeno djelo”. Stoga ne začuđuje činjenica da se izreka nulla poena sine culpa često koristi i u suvremenoj kaznenopravnoj doktrini ${ }^{45}$, kao i u suvremenoj nacionalnoj i europskoj pravnoj praksi. ${ }^{46}$

42 Vidi npr. Klarić, P.; Vedriš, M., op. cit. u bilj. 17, str. 381, 459, 480; Andrassy, J., Međunarodno pravo, Zagreb, 1990., str. 4, 339.

43 Vidi npr. odluke VSRH u predmetima II Rev-122/1995-2 od 29. siječnja 1998; Rev-3401/1994-2 od 12. veljače 1998.; II Rev-68/1995-2 od 26. veljače 1998.; Rev1959/1995-2 od 3. travnja 1998.; Revt-33/02-2 od 19. ožujka 2002.; Rev 328/13-2 od 5. rujna 2017.; Gž 12/2019-2 od 30. srpnja 2019.

44 O samoj reguli pacta sunt servanda usp. Liebs, D., op. cit. u bilj. 37, str. 150; Kranjc, J., op. cit. u bilj. 37, str. 181; Domingo, R. et al., op. cit. u bilj. 37, str. 321 - 323; Petrak, M., Traditio, op. cit. u bilj. 37, str. 105 - 106.

45 Vidi detaljnije u: Bojanić, I.; Mrčela, M., Koncepcija krivnje u novom Kaznenom zakonu, Hrvatski ljetopis za kazneno pravo i praksu, vol. 19, br. 2, 2012., str. 389 - 407, s uputama na daljnju literaturu; o samoj reguli nulla poena sine culpa, odnosno sine culpa, nisi subsit causa, non est aliquis puniendus usp. Liebs, D., op. cit. u bilj. 37, str. 198 - 199; Petrak, M., Traditio, op. cit. u bilj. 37, str. 97 - 98.

46 Vidi npr. odluke Ustavnog suda Republike Hrvatske u predmetima U-I-107/1995 te U-I-366/2000 od 19. lipnja 2002.; odluke Europskog suda za ljudska prava u predmetima Russian Conservative Party of Entrepreneurs and Others v. Rusija, br. 55066/00 
Kao odabrani primjer iznimno važnog suvremenog procesnopravnog načela koje je nastalo u srednjovjekovnom kanonskom pravu navedimo izreku nemo tenetur se ipsum accusare (lat. "nitko nije dužan sam sebe optuživati"). Navedena izreka sadržava pravilo prema kojem u sudskom postupku nitko nije dužan protiv sebe iznositi činjenice ili okolnosti koje bi mu mogle škoditi te se protiv takve osobe ne mogu u tom slučaju poduzimati nikakve prisilne mjere. Izreka je u navedenoj formulaciji prvi put sadržana u temeljnom djelu kanonističke pravne tradicije, Gracijanovu Dekretu (Decretum Gratiani, pars II, causa 33, questio 3, canon 87), te se često navodi kao klasični izraz "prava na šutnju”. U suvremenoj doktrini kaznenog procesnog prava ističe se da latinska izreka nemo tenetur se ipsum accusare označava privilegij od samooptuživanja kao jedno od temeljnih prava koja pripadaju okrivljeniku u kaznenom postupku. ${ }^{47}$ Navedeno pravo okrivljenika, nastalo u srednjovjekovnom kanonskom pravu te često nepoštovano u totalitarnim poretcima u 20. stoljeću, danas je iznova čvrsto ugrađeno u europske procesnopravne sustave. Tako, primjerice, u hrvatskom pravu Zakon o kaznenom postupku (čl. 239. st. 1. toč. 2.) određuje da pouka o pravima okrivljenika mora, među ostalim, sadržavati obavijest o tome da okrivljenik nije dužan iznijeti svoju obranu ni odgovarati na pitanja. U tom kontekstu posebice je zanimljivo istaknuti obrazloženje predlagatelja važećeg Zakona o kaznenom postupku uz navedenu odredbu, koje explicite aktualizira navedenu kanonsku pravnu izreku: “... jamstvo nemo tenetur se ipsum detegere je posebno značajno za ispitivanje okrivljenika i nalazi se u katalogu pouke o pravima iz članka 239. Nemo tenetur se ipsum detegere, jedno je od prava koja nisu izričito sadržana u Europskoj konvenciji, ali se uzima kao neartikulirano, u toj konvenciji sadržano pravo. Posebno je važno za sustave poput hrvatskog, koji osobu okrivljenika predviđaju i kao nositelja dokaza (odluka Europskog suda za ljudska prava u predmetu Saunders v. United

i 55638/00 od 11. travnja 2007. te H. W. K. v. Švicarska, br. 20241/92 od 29. studenoga 1995.; odluku Suda Europske Unije u predmetu Ebony Maritime SA and Loten Navigation Co. Ltd v. Prefetto della Provincia di Brindisi and others, C-177/95 od 27. veljače 1997. i dr.

47 V. npr. Krapac, D., Kazneno procesno pravo, Zagreb, 2003., str. 162 - 165. Prema shvaćanju današnje doktrine, navedeno načelo je važan aspekt pravičnog postupka “i usko je povezano s pretpostavkom okrivljenikove nedužnosti. Njegovo značenje sastoji se u okrivljenikovu pravu na uskratu iskaza i uskratu suradnje s državnim tijelima u kaznenom postupku protiv sebe" (cit. Đurđević, Z., Pravna osoba kao okrivljenik: temeljna prava i predstavljanje, Hrvatski ljetopis za kazneno pravo i praksu, vol. 12, br. 2, 2005., str. 757); o samoj reguli nemo tenetur se ipsum accusare usp. Liebs, D., op. cit. u bilj. 37, str. 134 - 135; Domingo, R. et al., op. cit. u bilj. 37, str. 288 - 289; Petrak, M., Traditio, op. cit. u bilj. 37, str. 92 - 93. 
Kingdom i dr.)" ${ }^{48}$ Navedena kanonoskopravna izreka ili njezine inačice poput nemo tenetur se ipsum prodere (lat. "nitko nije dužan sam sebe izdati”) izravno se na latinskom jeziku koriste i u suvremenoj europskoj pravnoj praksi. ${ }^{49}$

Nastojeći u ovom kratkom pregledu obuhvatiti načela iz temeljnih pravnih grana, sljedeća reprezentativna izreka kanonskog prava koju ćemo ukratko prikazati sadržava jedno važno načelo javnog prava: sede vacante nihil innovetur (lat. "dok je stolica prazna, neka se ne uvodi ništa novo”). U kanonskopravnoj tradiciji navedena se izreka u prvom redu odnosi na razdoblje u kojem je stolica rimskog biskupa (Cathedra Sancti Petri) prazna (sede vacante) zbog smrti pape. U tom slučaju, sukladno navedenom načelu, ništa se ne može mijenjati u upravi opće Crkve. Isto se načelo primjenjuje i za razdoblje kada biskupska stolica postaje prazna zbog smrti dijecezanskog biskupa, odreknućem koje prihvati papa, premještajem, ili oduzećem koje je priopćeno biskupu. Načelo sede vacante nihil innovetur sadržano je već u Dekretalima (Decretales) pape Grgura IX (X. 3, 9, l), a kodificirano je i u današnjem CIC-u, kan. 428 § 1. ${ }^{50}$ U kontekstu našeg javnog prava, imajući u vidu, primjerice, političko-pravne prijepore o tome koje bi poslove u praksi mogla obavljati "tehnička vlada”, čini se nedvojbenim da bi i na tu situaciju bilo optimalno primijeniti per analogiam opisano drevno načelo kanonskog prava.

Osim navedenih reprezentativnih načela kanonskog prava, na kojima se u znatnoj mjeri zasniva nekoliko najvažnijih suvremenih instituta civilnog prava, veliku važnost za današnje civilno pravo imaju i izreke kanonskog prava koje sadržavaju određena osnovna načela ili pravila o primjeni ili tumačenju prava. U nastavku ćemo ukratko raščlaniti samo dva primjera takvih izreka.

Prvi primjer jest izreka de similibus idem iudicium (lat. "o sličnome ista presuda"). Ona sadržava načelo da u sličnim slučajevima treba na sličan način i suditi. Navedena izreka zasniva se na pravnim shvaćanjima koja se u prvom redu odnose na primjenu analogije u suđenju. U širem smislu izreka govori i o nužnosti poštovanja ujednačene sudbene prakse kako se ne bi na isto ili vrlo slično činjenično stanje primjenjivale različite norme ili kriteriji. Sama formu-

48 Cit. Ministarstvo pravosuđa RH, Prijedlog Zakona o kaznenom postupku, lipanj 2008., str. 220.

49 Vidi primjerice odluku Suda Europske unije u predmetu Commission of the European Communities v SGL Carbon AG, C-301/04 P, od 29. lipnja 2006., ili izdvojeno mišljenje uz odluku Europskog suda za ljudska prava u predmetu Jalloh v. Njemačka, br. 54810/00, od 11. srpnja 2006.

50 O CIC-u, kan. 428 § 1. vidi npr. Mosconi, M., Sede vacante nihil innovetur: i limiti all'esercizio dell'autorità nella condizione di vacanza della sede, Quaderni di diritto ecclesiale, vol. 17, 2004., str. 146 - 175, s uputama na daljnju literaturu. 
lacija de similibus idem iudicium prvi je put u pravnom kontekstu korištena također u srednjovjekovnom kanonskom pravu, preciznije rečeno, u Dekretalima (Decretales) pape Grgura IX. (X. 1, 7, 2), a nalazimo je - primjerice - i u slavnom djelu sv. Tome Akvinskog Summa Theologiae (I-II, q. 2, a. 3, arg. 2). Pravno načelo sadržano u navedenoj izreci ugrađeno je posredstvom kanonske pravne tradicije i u suvremene pravne sustave. U hrvatskom je pravu to načelo konkretizirano, primjerice, u čl. 3. st. 1. Zakona o sudovima, koji određuje da je jedna od temeljnih funkcija sudova u Republici Hrvatskoj osigurati jedinstvenu primjenu prava, što je - sukladno čl. 20. toč. l. istog Zakona - u posebnom smislu zadaća Vrhovnog suda Republike Hrvatske. ${ }^{51}$

Drugi primjer može predstavljati izreka dubia in meliorem partem interpretari debent (lat. "dvojbeno treba tumačiti u povoljnijem smislu"), koja sadržava shvaćanje da pravne akte (pravne propise, pravne poslove) treba u slučaju njihova dvojbenog značenja uvijek tumačiti na povoljniji način, u smislu da se time ne povrijede pravni interesi subjekata na kojih se odnosi takav pravni akt. Navedena izreka formulirana je na temelju fragmenta klasičnog rimskog pravnika Marcela (Marcellus) (Digesta 50, 17, 192, 1) u srednjovjekovnom kanonskom pravu, preciznije rečeno, u Dekretalima (Decretales) pape Grgura IX (X. 5, 41, 2). Izreka dubia in meliorem partem interpretari debent nedvojbeno je zadržala svoju aktualnost i danas, a interpretacijsko pravilo sadržano u njoj preuzeto je posredstvom kanonske pravne tradicije u suvremene pravne sustave. ${ }^{52}$ Tako, primjerice, u hrvatskom pravu, sukladno čl. 50. st. 3. Zakona o nasljeđivanju, u dvojbi o pravoj oporučiteljevoj namjeri treba se držati onoga što je povoljnije za osobu koja je oporukom nečim opterećena. ${ }^{53}$

Spomenuti primjeri koji zorno svjedoče o veliku značenju kanonskog prava za nacionalnu i europsku pravnu tradiciju te suvremene pravne sustave mogli bi se nizati gotovo unedogled. Navedena problematika iznimno je detaljno analizirana u nedavno izašloj petotomnoj epohalnoj sintezi Der Einfluss der Kanonistik auf die europäische Rechtskultur, pa čitatelje koji imaju interesa saznati mnogo više o tim pitanjima upućujemo na navedeno djelo. ${ }^{54}$

${ }^{51}$ O reguli de similibus idem iudicium vidi npr. Domingo, R. et al., op. cit. u bilj. 37, str. 148; Petrak, M., Traditio, op. cit. u bilj. 37, str. 47; o jedinstvenoj primjeni prava usp. npr. Bratković, M., Što je važno pitanje u reviziji?, Zbornik Pravnog fakulteta u Zagrebu, vol. 68, br. 5-6, 2018., str. 853 - 880 .

52 O samoj reguli dubia in meliorem partem interpretari debent usp. Domingo, R. et al., op. cit. u bilj. 37, str. 166 - 167; Petrak, M., Traditio, op. cit. u bilj. 37, str. 51.

53 Usp. Gavella, N.; Belaj, V., Nasljedno pravo, Zagreb, 2008., str. 173 - 174.

54 Condorelli, O.; Roumy, F.; Schmoeckel, M.; Mausen Y.; von Mayenburg, D., Der Einfluss der Kanonistik auf die europäische Rechtskultur: Bd. 1: Zivil- und Zivilprozessrecht; 
U domaćem je kontekstu, međutim, nemoguće oteti se dojmu da je gotovo posvemašnja eliminacija kanonskog prava kao nadasve važne sastavnice europske pravne tradicije iz programa pravnog studija u posljednjih sedamdesetak godina nedvojbeno pridonijela osiromašenju hrvatske pravne kulture. ${ }^{55}$

\subsection{Regulae iuris canonici kao izvor hrvatskog prava}

Kako smo upravo vidjeli, nedvojbeno je da se i suvremeni pravni sustavi mogu referirati na načela kanonskog prava kao pravna načela na kojima se u znatnoj mjeri zasnivaju važni instituti suvremenih pravnih sustava ili pak kao na pravna načela kojima je svrha popuna pravnih praznina, odnosno preciznija interpretacija postojećih pravnih normi. Međutim, postavlja se pitanje je li moguća izravna primjena načela kanonskog prava u suvremenom hrvatskom

Bd. 2: Öffentliches Recht; Bd. 3: Straf- und Strafprozessrecht; Bd. 4: Prozessrecht; Bd. 5: Das Recht der Wirtschaft, Wien/Köln/Weimar, 2009. - 2016.; kratku uvodnu studiju o navedenoj problematici pružio je svojedobno Landau, P., Der Einfluß des kanonischen Rechts auf die europäische Rechtskultur, u: Schulze, R. (ed.), Europäische Rechts- und Verfassungsgeschichte. Ergebnisse und Perspektiven der Forschung, Berlin, 1991., str. 39 - 57.

55 Premda se na Pravnom fakultetu Sveučilišta u Zagrebu, jednako kao i na Katoličkom bogoslovnom fakultetu, kanonsko pravo predavalo od njegova osnivanja (1776.) kao obvezatni predmet, nastava iz kanonskog prava, jednako kao i katedra kanonskog prava, ukinuti su iz ideoloških razloga 1945. Tome nasuprot, katedra kanonskog prava, koja izvodi čak nekoliko obvezatnih predmeta tijekom filozofsko-teološkog studija, postoji kontinuirano sve do danas na Katoličkom bogoslovnom fakultetu; o toj problematici vidi detaljnije u: Berljak, M., Katedra kanonskoga prava Katoličkoga bogoslovnog fakulteta Sveučilišta u Zagrebu, Tkalčić. Godišnjak Društva za povjesnicu Zagrebačke nadbiskupije, vol. 9, 2005., str. 411 - 442. Ipak, u najnovije vrijeme, nakon određenih pokušaja u 1990-ima, otvorila se i na Pravnom fakultetu mogućnost za uvođenje novih izbornih kolegija koji obuhvaćaju (i) određene sadržaje iz kanonskog prava u njihovu odnosu sa svjetovnim pravom pod nazivima "Religija, pravo i društvo" te "Kanonsko pravo i hrvatski pravni sustav". U tom kontekstu treba istaknuti i da je Pravni fakultet Sveučilišta u Splitu uveo prije desetak godina u svoj studijski program kanonsko pravo kao izborni predmet. Za razliku od višedesetljetne situacije u Hrvatskoj, kanonsko je pravo na pravnim fakultetima u mnoštvu europskih država sasvim uobičajen dio studijskog programa, a njegov kurikularni status varira od obligatornog predmeta, preko predmeta određenog smjera pa do izbornog predmeta. U navedenom kontekstu treba istaknuti da pojedini ugledni europski pravni fakulteti (npr. Lateranum u Rimu ili švicarski Fribourg) i danas omogućuju - nastavljajući drevnu tradiciju koja je otpočela sa samim srednjovjekovnim nastankom institucije sveučilišta - zajednički studij civilnog i kanonskog prava te se osobama koje su završile najviši stupanj takvog studija dodjeljuje prestižna titula iuris utriusque doctor (hrv. "doktor obaju prava”, tj. civilnog i kanonskog prava). 
pravu kao pravnog izvora. Drugim riječima kazano, postoji li u hrvatskom pravnom sustavu - ostavljajući u ovoj prigodi po strani međunarodne ugovore između Svete Stolice i Republike Hrvatske - pozitivnopravni temelj za direktnu primjenu načela kanonskog prava?56

Pri pokušaju adekvatnog odgovora na to pitanje jedini je mogući put krenuti od teksta Zakona o načinu primjene pravnih propisa donesenih prije 6. travnja 1941. godine (dalje u tekstu: ZNPP), koji je stupio na snagu 31. prosinca 1991. ${ }^{57}$ Prema odredbama navedenog Zakona pravni propisi koji su bili na snazi na dan 6 . travnja 1941. godine primjenjivat će se u Republici Hrvatskoj kao pravna pravila na odnose koji nisu uređeni važećim propisima Republike Hrvatske ako su u skladu s Ustavom i zakonima Republike Hrvatske te ako su, sukladno posebnim propisima, do dana stupanja na snagu ovoga zakona, primjenjivana u Republici Hrvatskoj (čl. 1. - 2. ZNPP-a). Osnovni ratio navedenog zakona jest popuna pravnih praznina koje postoje u pravnom sustavu RH putem primjene pravnih propisa koji su bili na snazi na teritoriju današnje RH na dan 6. travnja 1941.58 Navedenim Zakonom zapravo je određeno da svi pravni propisi iz svih pravnih poredaka koji su važili 6. travnja 1941. na području današnje RH mogu postati supsidijarno pravo u rangu pravnih pravila ako ispunjavaju sljedeća tri uvjeta: 1) da su do 31. prosinca 1991. primjenjivani na području današnje Hrvatske; 2) da postoji pravna praznina na koju se pojedini pravni propis može primijeniti; 3) da su u skladu s Ustavom i zakonima RH.

Od navedenih triju uvjeta spornim se čini jedino značenje prvog od njih. Prema našem mišljenju jedino razborito tumačenje jest da se kao supsidijarno pravo, uz ispunjenje drugog i trećeg navedenog uvjeta, mogu primijeniti svi oni propisi koji su bili na snazi 6. travnja 1941., ako su u bilo kojem vremenskom periodu između 6. travnja 1941. (dies a quo) i 31. prosinca 1991. (dies ad quem) važili na teritoriju današnje RH. Primjenom bilo kojeg drugog kriterija, kako

56 Polazište raščlambe sadržane u toč. 4.2. jest analiza izvršena u jednom segmentu rada Petrak, M., Utrumque ius i suvremeni pravni sustavi, u: Škalabrin, N. (ur.), Franjo Herman i Kodeks iz 1917. Suum cuique tribuere, Đakovo, 2008., str. 137 - 149, uz drukčiju impostaciju, kontekstualizaciju i svrhu raščlambe.

57 Narodne Novine, br. 73/1991.

58 O Zakonu o načinu primjene pravnih propisa donesenih prije 6. travnja 1941. godine vidi u: Klarić, P.; Vedriš, M., op. cit. u bilj. 17, str. 19 - 20; Gavella, N. et al., Hrvatsko građanskopravno uređenje i kontinentalnoeuropski pravni krug, Zagreb, 1994., str. 170 - 171; Stipković, Z. (ur.), Zakon o osnovnim vlasničkopravnim odnosima, Zagreb, 1991., str. 6. 
smo detaljnije objasnili na drugom mjestu ${ }^{59}$, navedeni Zakon uopće ne bi mogao ispuniti svoju svrhu.

Međutim, glede središnje problematike ovog dijela naše raščlambe, tj. pitanja mogu li načela kanonskog prava biti izvorom suvremenog prava $\mathrm{u}$ RH, kako, primjerice, $\mathrm{u}$ svrhu popune pravnih praznina, tako u svrhu preciznije interpretacije postojećih pravnih normi, mnogo je važnije razmotriti pitanje omogućava li uopće ZNPP na bilo koji način primjenu načela kanonskog prava kao važećeg prava.

U traganju za odgovorom na navedeno pitanje treba krenuti od činjenice da je tradicionalno ugarsko pravo ${ }^{60}$ - utemeljeno još na Werböczyevu Tripartitu iz 1514. te brojnim kasnijim propisima, koji su svi zajedno sačinjavali Corpus iuris hungarici kao zbirku svekolikog ugarskog prava ${ }^{61}$ - važilo na određenim područjima (Međimurje, Baranja) današnje RH na dan 6. travnja 1941. U doba socijalističke Jugoslavije, zahvaljujući prihvaćanju pravno-političkog načela "jedinstva prava" 62 , određeni segmenti ugarskog prava primjenjivali su se kao supsidijarno pravo na cijelom hrvatskom teritoriju sve do osamostaljenja RH. Nakon osamostaljenja RH sudska praksa nastavila je primjenjivati - na temelju ZNPP-a - pojedina pravila ugarskog prava kao supsidijarno pravo, primjerice u području zemljišnoknjižnog prava, rukovodeći se pri tome i nadalje načelom

59 Vidi detaljnije u: Petrak, M., Rimsko pravo kao pozitivno pravo u Republici Hrvatskoj. Prilog tumačenju Zakona o načinu primjene pravnih propisa donesenih prije 6. travnja 1941. godine, Hrvatska pravna revija, vol. 6, 2006., str. 1 - 11 (dalje cit. Petrak, M., Rimsko pravo).

60 Općenito o šest različitih pravnih područja u Kraljevini SHS, odnosno Kraljevini Jugoslaviji vidi u: Radovčić, V., Pokušaj kodifikacije građanskog prava u staroj Jugoslaviji ("Predosnova građanskog zakonika za Kraljevinu Jugoslaviju”), Radovi Instituta za hrvatsku povijest, vol. 7, 1975., str. 253 - 257, s uputama na daljnju literaturu.

${ }_{61}$ O nastanku, značenju i strukturi Corpus iuris hungarici vidi u: Lanović, M., Privatno pravo Tripartita, Zagreb, 1929., str. 93 - 98; općenito o vrelima ugarskog prava primjenjivanog u pojedinim područjima međuratne Jugoslavije vidi npr. u: Milić, I., Pregled madžarskog privatnog prava u poredjenju sa austrijskim građanskim zakonikom, Subotica, 1921., str. 7 - 11 .

O spomenutom načelu “jedinstva prava”, kojim je u socijalističkoj Jugoslaviji pri rješavanju konkretnog slučaja - u nedostatku poslijeratnih propisa - postavljen kriterij da se kao ius in subsidio trebaju primijeniti pravna pravila koja je sudska praksa, bez obzira na činjenicu s kojeg su od šest predratnih pravnih područja potjecala, smatrala najprikladnijim i najsuvremenijim, a ne pravna pravila onog pravnog poretka koji je na odnosnom području vrijedio na dan 6. travnja 1941. godine., vidi u: Gavella, N., Građansko pravo u Hrvatskoj i kontinentalno-europski pravni krug - u povodu 140. godišnjice stupanja na snagu OGZ u Hrvatskoj, Zbornik Pravnog fakulteta u Zagrebu, vol. 43, 1993., str. 358 - 359, s uputama na daljnju literaturu. 
“jedinstva prava” kao mjerodavnog kriterija ${ }^{63} \mathrm{U}$ tom kontekstu posebice je interesantno istaknuti da je RH jedina država u kojoj je još moguće primijeniti Corpus iuris hungarici, s obzirom na to da su pravni propisi sadržani u navedenoj zbirci odavno derogirani u Mađarskoj i Slovačkoj donošenjem građanskih kodifikacija nakon Drugog svjetskog rata. ${ }^{64}$

S obzirom na temu ovog dijela naše raščlambe vrlo je važno napomenuti da je u Corpus iuris hungarici kao njegov integralni dio preuzet posljednji titul posljednje knjige Justinijanovih Digesta (D. 50,17), koji nosi ime De diversis regulis iuris antiqui. Navedeni titul, nedvojbeno jedan od najznamenitijih dijelova Justinijanove kodifikacije, sadržava 211 kratkih fragmenata rimskih pravnika u kojima su u obliku regula sažeta temeljna rimska pravna načela na kojima je u potonjim vremenima u relevantnoj mjeri sazdana europska pravna kultura i europski pravni sustavi. ${ }^{65}$ Navedeni titul Digesta uključio je već u prvo izdanje Corpus iuris hungarici iz 1581. godine njegov prireditelj, ugarski humanist Iohannes Sambucus (János Zsámboki) $(1531 .-1584 .)^{66}$, čime su u njemu sadržana pravna pravila postala izvor prava u Ugarsko-Hrvatskom Kraljevstvu. Navedenim je rimskim pravnim regulama - u izdanju Corpus-a iz 1751., koje je u Trnavi uredio isusovac János Szegedy (1699. - 1760.) - pridodano, osim 205 regula ugarskog prava, još i 99 već spominjanih srednjovjekovnih regula kanonskog prava. Od toga je prvih 11 regula preuzeto iz Dekretala pape Grgura IX., a ostalih 88 regula iz Liber Sextus pape Bonifacija VIII.: znatna većina njih ima značenje općih pravnih načela. ${ }^{67}$ Tako su navedena rimska, ugarska i kanonska pravna pravila, pod skupnim imenom Diversae regulae juris antiqui, hungarici et canonici, postala integralnim dijelom Corpus iuris hungarici,

63 Tako je, primjerice, sve do 1. siječnja 1997. godine, tj. do stupanja na snagu važećeg Zakona o zemljišnim knjigama, primjenjivan ugarski Zakonski članak XXIX o sastavljanju gruntovnih uložaka iz 1886. godine; vidi Gavella et al., op. cit. u bilj. 58, str. 130, bilj. 354.

${ }^{64}$ U Mađarskoj je građanski zakonik donesen 1959., a u Čehoslovačkoj 1950.; usp. Hamza, G., Die Entwicklung des Privatrechts auf römischrechtlicher Grundlage unter besonderer Berücksichtigung der Rechtsentwicklung in Deutschland, Österreich, der Schweiz und Ungarn, Budapest, 2002., str. 139 - 142; 184.

65 O titulu De diversis regulis iuris antiqui, njegovoj strukturi, sadržaju i značenju u europskoj pravnoj tradiciji vidi amplius u: Stein, P., The Digest Title, De diversis regulis iuris antiqui and the General Principles of Law, u: Newman, R. A. (ed.), Essays in Jurisprudence in Honor of Roscoe Pound, Indianopolis/New York, 1962., str. 1 - 20, s uputama na daljnju literaturu.

66 Mora, M., Über den Unterricht des römischen Rechtes in Ungarn in den letzten hundert Jahren, Revue internationale des droit de l'antiquité (RIDA), vol. 11, 1964., str. 413; Hamza, G., op. cit. u bilj. 64, str. 133.

67 Usp. supra pod 3. 
a time i pravnim izvorom ugarskog prava. ${ }^{68}$ Budući da u potonjim vremenima nema ni najmanjeg traga o tome da bi navedene regule prestale biti sastavnim dijelom ugarskog pravnog sustava ${ }^{69}$, nedvojbeno je da su još uvijek imale status pravnog izvora i 6. travnja 1941. godine u hrvatskim krajevima pripadnim bivšem ugarskom pravnom području (Međimurje, Baranja). Stoga smatramo da i danas odnosne rimske i kanonske pravne regule treba tretirati - vodeći pri tome računa o spomenutom načelu "jedinstva prava” - kao potencijalno supsidijarno pravo u RH u smislu odredbi ZNPP-a.

U pogledu rimskog prava eminentni hrvatski pravni praktičari, slijedeći naše svojedobne raščlambe o toj problematici ${ }^{70}$, prihvatili su zaključak da temeljem ZNPP-a "rimska pravna pravila mogu imati (imaju!) status izvora suvremenog hrvatskog pozitivnog prava". ${ }^{71}$ Nedvojbeno se isto može reći i za spomenute regule kanonskog prava, sabrane u okviru cjeline pod naslovom Diversae regulae juris antiqui, hungarici et canonici kao integralne sastavnice Corpus iuris hungarici.

U tom kontekstu posebice je zanimljivo istaknuti da se novija i recentna hrvatska sudska praksa u obrazloženjima svojih odluka višekratno i explicite, na latinskom jeziku, pozvala na pojedine regule ili njihove skraćene varijante, koje su izvorno sadržane u navedenom titulu Liber Sextus pape Bonifacija VIII. Osim već spomenute nulla poena sine culpa kao skraćene forme regule sine culpa, nisi subsit causa, non est aliquis puniendus (Liber Sextus, 5, 13, 23) ${ }^{72}$, tako su, primjerice, navedene i regule: ignorantia iuris non excusat ("neznanje prava ne ispričava") kao varijanta ignorantia facti, non iuris excusat ("neznanje činjenice, a ne prava, ispričava”) (Liber Sextus, 5,13,13) ${ }^{73}$; accessorium sequitur principale ("pripadak slijedi glavnu stvar") kao skraćena inačica accessorium naturam sequi congruit principalis ("pripadak

68 Usp. Lanović, M., op. cit. u bilj. 61, str. 96.

69 Tako je, primjerice, Ivo Milić već na samom početku svojeg djela Pregled madžarskog privatnog prava u poredjenju sa austrijskim građanskim zakonikom, izdanog 1921. g., odlučno isticao da gdje "nema pozitivnih propisa, treba bez bojazni primjenjivati načela općeg prava”, čiji su iskazi par excellence upravo regule rimskog i kanonskog prava; cit. Milić, I., op. cit. u bilj. 61, str. 1.

70 Petrak, M., Rimsko pravo, op. cit. u bilj. 59, str. 1 - 11.

71 Cit. Žuvela, M., Vlasničkopravni odnosi, Zagreb, 2009., str. 6.

72 Vidi supra pod 4.1.

73 Vidi npr. odluke Pž-7142/07-4 od 2. srpnja 2008.; Pž-6599/05-4 od 14. prosinca 2005. (Visoki trgovački sud RH); o reguli ignorantia iuris non excusat, odnosno ignorantia facti, non iuris excusat, usp. Liebs, D., op. cit. u bilj. 37, str. 86; Domingo, R. et al., op. cit. u bilj. 37, str. 203; Petrak, M., Traditio, op. cit. u bilj. 37, str. 65 - 66. 
slijedi narav glavne stvari”) (Liber Sextus, 5, 13, 42) 74 ; qui tacet, consentire videtur ("tko šuti, smatra se da pristaje") (Liber Sextus, 5, 13, 43)75; prior tempore, potior iure ("raniji u vremenu, jači u pravu") kao skraćena forma qui prior est tempore, potior est iure ("tko je raniji u vremenu, jači je u pravu") (Liber Sextus, 5, 13, 54)76 itd.

\section{ZAKLJUČNE NAPOMENE}

Sve do sada navedene činjenice nedvojbeno dokazuju da su navedene regule kanonskog prava prihvaćene kao važeći normativni sadržaji u hrvatskoj sudskoj praksi. Međutim, upravo provedena raščlamba o regulama iz Liber Sextus 5, 13 ima za cilj ukazati na činjenicu da bi hrvatska sudska praksa zasigurno mogla otići i korak dalje u smislu da se regulae iuris canonici sadržane u Corpus iuris hungarici ne primjenjuju samo kao puki argument ili “ornament” u obrazloženju sudskih odluka, bez navođenja njihova izvora. Štoviše, smatramo da se navedeni

74 Vidi npr. odluke Gž-1172/2018-2 od 10. svibnja 2018. (Županijski sud u Splitu); P-1799/98-47 od 20. svibnja 2003. (Općinski sud u Varaždinu); o reguli accessorium sequitur principale, odnosno accessorium naturam sequi congruit principalis, usp. Liebs, D., op. cit. u bilj. 37, str. 22; Domingo, R. et al., op. cit. u bilj. 37, str. 321 - 323; Petrak, M., Traditio, op. cit. u bilj. 37, str. 16. Navedeno načelo preuzeto je i u suvremeno građansko pravo. Tako je, primjerice, u hrvatskom pravu, sukladno čl. 5. st. 2. Zakona o vlasništvu i drugim stvarnim pravima, određeno da tko ima pravo vlasništva ili koje od drugih stvarnih prava na nekoj stvari, ima ga time i na svim njezinim pripadnostima.

75 Vidi npr. odluku Pž-1030/06-3 od 18. lipnja 2007. (Visoki trgovački sud RH); P-339/00-14 od 1. lipnja 2001. (Općinski sud u Zlataru); o reguli qui tacet, consentire videtur usp. Liebs, D., op. cit. u bilj. 37, str. 177; Kranjc, J., op. cit. u bilj. 37, str. 206; Domingo, R. et al., op. cit. u bilj. 37, str. 355 - 356; Petrak, M., Traditio, op. cit. u bilj. 37, str. 114 - 115. Potrebno je napomenuti da regula qui tacet, consentire videtur ima široko polje primjene u suvremenom hrvatskom građanskom procesnom pravu. Prema mišljenju naše doktrine, navedena je regula dogmatski temelj procesnih odredbi Zakona o parničnom postupku koje reguliraju pravne posljedice slučajeva potpune pasivnosti tuženika u parnici, ponajprije institute presude zbog ogluhe i presude zbog izostanka (vidi Triva, S.; Dika, M., Građansko parnično procesno pravo, Zagreb, 2004., str. 155 - 157).

76 Vidi npr. odluku P-2/2002 od 3. srpnja 2002. (Trgovački sud u Zagrebu); o reguli prior tempore, potior iure, odnosno qui prior est tempore, potior est iure, usp. Liebs, D., op. cit. u bilj. 37, str. 176; Kranjc, J., op. cit. u bilj. 37, str. 191.; Domingo, R. et al., op. cit. u bilj. 37, str. 340; Petrak, M., Traditio, op. cit. u bilj. 37, str. 113. To je pravilo preuzeto i u suvremene pravne sustave, pa tako i u hrvatsko pravo, koje, primjerice, u čl. 302. st. 2. Zakona o vlasništvu i drugim stvarnim pravima određuje da ako je zalog opterećen s više založnih prava, prednost pri namirivanju ima ona tražbina koja je ispred ostalih u prvenstvenom redu. 
segment kanonskog prava, u vidu pravnih načela, može - pod uvjetima određenim ZNPP-om - primijeniti kao važeće pravo u RH te si pri tome "posvijestiti" te precizno navesti njegov izvor u svakom pojedinom slučaju. Stoga smo u prilogu ovog rada po prvi put pružili cjeloviti hrvatski prijevod s latinskog jezika spomenutih 11 regula iz Dekretala pape Grgura IX. te 88 regula iz Liber Sextus pape Bonifacija VIII. kao sastavnog dijela Corpus iuris hungarici kako bi se pravna doktrina te posebice sudska praksa mogla bolje upoznati s tim svevremenim pravnim načelima te ih - na tragu već otpočete uporabe u citiranim sudskim odlukama - što adekvatnije primjenjivati kao dio hrvatskog pravnog sustava.

Premda navedene regule kanonskog prava $\mathrm{u}$ formalnom smislu mogu imati status tek podrednog izvora prava, u sadržajnom smislu one mogu biti od fundamentalnog značenja za suvremeni pravni sustav s obzirom na to da čitav niz takvih pravila sadržava temeljna pravna načela na kojima se u znatnoj mjeri zasniva relevantan broj najvažnijih suvremenih pravnih instituta. Stoga bi prihvaćanje spomenutih regula kao supsidijarnog izvora važećeg prava od strane sudske prakse i pravne doktrine moglo u relevantnoj mjeri pridonijeti ispravnom tumačenju i primjeni suvremenih pravnih propisa, a pravna bi praksa mogla u mnogo većem i preciznije definiranom opsegu nego što je to do sada bio slučaj, tj. pod uvjetima određenim ZNPP-om, izravno primijeniti pravna načela sadržana u tim pravilima - u slučaju postojanja pravnih praznina ili uz usporednu primjenu suvremenih pravnih normi koje se temelje na navedenim načelima - s ciljem usavršavanja hrvatskog pravnog sustava.

Polazeći od spomenute činjenice da pravila rimskog i kanonskog prava formulirana u obliku latinskih pravnih regula predstavljaju tradicionalni sažeti izraz same biti europske pravne tradicije i kulture ${ }^{77}$, postavlja se zaključno i pitanje u kojoj bi mjeri njihova ekstenzivnija primjena u pravnoj praksi mogla pridonijeti daljnjoj europeizaciji nacionalnih pravnih sustava. U novijim analizama, koje, inter alia, obrađuju i pitanje primjene takvih regula od strane europskih sudskih tijela, kako u slučaju postojanja pravnih praznina u europskom pravnom poretku, tako i u svrhu preciznije interpretacije njegovih postojećih pravnih normi, posebice se ističe da sustavna primjena takvih pravila kao općih pravnih načela zajedničkih svim nacionalnim europskim pravnim sustavima pripadnim tradiciji rimskog i kanonskog prava predstavlja, uz različite vrste legislativnih akata, jedan od načina daljnje harmonizacije i/ili unifikacije europskog pravnog prostora. ${ }^{78}$ Osim brojnih drugih pravila rimskog i kanonskog prava, tako ćemo,

77 Usp. supra pod 4.1.

78 Vidi npr. Knütel, R., Ius commune und Römisches Recht vor Gerichten der Europäischen Union, Juristische Schulung, Heft 9, 1996., str. 768 - 778; usp. i Wacke, A., op. cit. 
primjerice, u europskoj sudskoj praksi naići i na eksplicitno navođenje u ovom radu već spomenutih regula iz Liber Sextus 5, 13: ignorantia iuris non excusat ${ }^{79}$; accessorium sequitur principale ${ }^{80}$; prior tempore, potior iure. ${ }^{81}$

Polazeći od navedenog konteksta, nije teško doći do spoznaje da bi sustavna primjena na nacionalnim razinama i regula kanonskog prava koje u sebi sadržavaju opća načela prava, a na koje se, kako vidimo, referira i europska sudska praksa, pridonijela u relevantnoj mjeri daljnjoj europeizaciji nacionalnih pravnih sustava u Europi. Ako se ima u vidu te odgovarajuće shvati opisana praktična funkcija kanonske pravne tradicije u suvremenom svijetu, zaključno treba ustvrditi da mogući širi razmjeri primjene regula kanonskog prava u hrvatskoj sudskoj praksi ne bi predstavljali samo nostalgično traganje za skrivenim blagom europske pravne tradicije, već jedan dio dugotrajnog kreativnog napora za europeizacijom suvremenih pravnih sustava na čvrstim temeljima zajedničke pravne kulture.

u bilj. 37, str. 174 - 213, koji napose naglašava ulogu latinskih pravnih regula i u njima sadržanih pravnih načela u procesu europeizacije privatnog prava; posebice o značenju i funkciji kanonskog prava u navedenom kontekstu vidi npr. Scholler, H. (ed.), Die Bedeutung des kanonischen Rechts für die Entwicklung einheitlicher Rechtsprinzipien, Baden-Baden, 1996.

79 Vidi npr. Sud Europske unije, Mišljenje nezavisnog odvjetnika u predmetu C-551/03 P. od 25. listopada 2005.

80 Vidi npr. Sud Europske unije, Presuda u predmetu C-6/01 od 11. rujna 2003.

81 Vidi npr. Sud Europske unije, Mišljenje nezavisnog odvjetnika u predmetu C-569/08 od 10. veljače 2010 . 
PRILOG:

\section{REGULAE IURIS CANONICI}

(Pravila kanonskog prava primjenjiva sukladno Zakonu o načinu primjene pravnih propisa donesenih prije 6. travnja 1941. godine)

Dekretali (Decretales) pape Grgura IX. (1234. g.) (lib. V. tit. XLI., de regulis iuris)

\begin{tabular}{|c|l|l|}
\hline 1 & $\begin{array}{l}\text { Omnis res, per quascunque causas } \\
\text { nascitur, per easdem dissolvitur. }\end{array}$ & $\begin{array}{l}\text { Svaka stvar, nastala iz određenih } \\
\text { razloga, istim razlozima i prestaje. }\end{array}$ \\
\hline 2 & $\begin{array}{l}\text { Facta, quae, dubium est, quo } \\
\text { animo fiant, in meliorem partem } \\
\text { interpretemur. }\end{array}$ & $\begin{array}{l}\text { Trebamo u povoljnijem smislu } \\
\text { tumačiti čine glede kojih postoji } \\
\text { dvojba s kojom su namjerom } \\
\text { učinjeni. }\end{array}$ \\
\hline 3. & $\begin{array}{l}\text { Utilius scandalum nasci permittitur, } \\
\text { quam veritas relinquatur. }\end{array}$ & $\begin{array}{l}\text { Bolje je dopustiti nastanak sablazni } \\
\text { nego izdati istinu. }\end{array}$ \\
\hline 4. & $\begin{array}{l}\text { Quod non est licitum in lege, necessitas } \\
\text { facit licitum. }\end{array}$ & $\begin{array}{l}\text { Šo nije dopušteno zakonom, učini } \\
\text { dopuštenim nužda. }\end{array}$ \\
\hline 5. & $\begin{array}{l}\text { Quod latenter, aut per vim, vel alias } \\
\text { sticite introductum est, nulla debet }\end{array}$ & $\begin{array}{l}\text { Ono što je uvedeno potajno ili } \\
\text { silom ili na drugi nezakonit način, } \\
\text { ne smije postati trajno. }\end{array}$ \\
\hline 6. & $\begin{array}{l}\text { In ipso causae initio est a quaestionibus } \\
\text { inchoandum. }\end{array}$ & $\begin{array}{l}\text { Na samom početku postupka treba } \\
\text { krenuti s istragom. }\end{array}$ \\
\hline 7. & $\begin{array}{l}\text { Quidquid in sacratis Deo rebus et } \\
\text { episcopis iniuste agitur, pro sacrilegio } \\
\text { reputatur. }\end{array}$ & $\begin{array}{l}\text { Svako oskvrnuće stvari posvećenih } \\
\text { Bogu, te biskupa, smatra se } \\
\text { svetogrđem. }\end{array}$ \\
\hline 8. & $\begin{array}{l}\text { Qui ex timore facit praeceptum, aliter, } \\
\text { quam debeat, facit, et ideo iam non } \\
\text { facit. }\end{array}$ & $\begin{array}{l}\text { Tko izvrši zapovijed zbog straha, } \\
\text { izvršio je nešto drugo nego što } \\
\text { je trebao te je stoga, štoviše, nije } \\
\text { izvršio. }\end{array}$ \\
\hline I0ffendens in uno factus est omnium \\
reus. \\
$\begin{array}{l}\text { Non potest esse pastoris excusatio, si } \\
\text { lupus oves comedit, et pastor nescit. }\end{array}$ & $\begin{array}{l}\text { Počinitelj jednog (grijeha) kriv je } \\
\text { kao da je počinio sve (grijehe). }\end{array}$ \\
\hline $\begin{array}{l}\text { Ne može postojati isprika za } \\
\text { pastira ako mu vuk pojede ovce, a } \\
\text { pastir to ne zna. }\end{array}$ \\
quis homagium compellatur.
\end{tabular}


Liber Sextus pape Bonifacija VIII. (1298. g.) (lib. V. tit. XIII., de regulis iuris)

\begin{tabular}{|c|c|c|}
\hline 1 & $\begin{array}{l}\text { Beneficium ecclesiasticum non potest } \\
\text { licite sine institutione canonica obtineri. }\end{array}$ & $\begin{array}{l}\text { Crkvena povlastica ne može } \\
\text { se steći na dopušten način bez } \\
\text { kanonskog osnutka. }\end{array}$ \\
\hline 2 & $\begin{array}{l}\text { Possessor malae fidei ullo tempore non } \\
\text { praescribit. }\end{array}$ & $\begin{array}{l}\text { Nepošteni posjednik nikad ne } \\
\text { stječe vlasništvo dosjelošću. }\end{array}$ \\
\hline 3 & $\begin{array}{l}\text { Sine possessione praescriptio non } \\
\text { procedit. }\end{array}$ & Bez posjeda nema dosjelosti. \\
\hline 4 & $\begin{array}{l}\text { Peccatum non dimittitur, nisi } \\
\text { restituatur ablatum. }\end{array}$ & $\begin{array}{l}\text { Grijeh se ne odrješuje ako nije } \\
\text { izvršena pokora. }\end{array}$ \\
\hline 5 & Peccati venia non datur nisi correcto. & $\begin{array}{l}\text { Oprost grijeha ne daje se bez } \\
\text { popravka. }\end{array}$ \\
\hline 6 & Nemo potest ad impossibile obligari. & $\begin{array}{l}\text { Nitko se ne može obvezati na } \\
\text { nemoguće. }\end{array}$ \\
\hline 7 & $\begin{array}{l}\text { Privilegium personale personam } \\
\text { sequitur et extinguitur cum persona. }\end{array}$ & $\begin{array}{l}\text { Osobna povlastica slijedi osobu i } \\
\text { prestaje sa smrću osobe. }\end{array}$ \\
\hline 8 & $\begin{array}{l}\text { Semel malus semper praesumitur esse } \\
\text { malus. }\end{array}$ & $\begin{array}{l}\text { Tko je jednom bio zao (kriv), } \\
\text { predmnijeva se da je uvijek kriv. }\end{array}$ \\
\hline 9 & $\begin{array}{l}\text { Ratum quis habere non potest, quod } \\
\text { ipsius nomine non est gestum. }\end{array}$ & $\begin{array}{l}\text { Ne može netko naknadno odobriti } \\
\text { ono što nije učinjeno u njegovo } \\
\text { ime. }\end{array}$ \\
\hline 10 & $\begin{array}{l}\text { Ratihabitionem retrotrahi et mandato } \\
\text { non est dubium comparari. }\end{array}$ & $\begin{array}{l}\text { Naknadno odobrenje djeluje } \\
\text { unatrag i nedvojbeno se izjednačuje } \\
\text { s nalogom. }\end{array}$ \\
\hline 11 & $\begin{array}{l}\text { Cum sunt partium iura obscura, reo } \\
\text { favendum est potius quam actori. }\end{array}$ & $\begin{array}{l}\text { Ako su prava (parničnih) stranaka } \\
\text { sporna, treba više ići u prilog } \\
\text { tuženome nego tužitelju. }\end{array}$ \\
\hline 12 & $\begin{array}{l}\text { In iudiciis non est acceptio personarum } \\
\text { habenda. }\end{array}$ & $\begin{array}{l}\text { U sudskim postupcima ne uzima } \\
\text { se u obzir ugled osoba. }\end{array}$ \\
\hline 13 & Ignorantia facti, non iuris excusat. & $\begin{array}{l}\text { Neznanje činjenice, a ne prava, } \\
\text { ispričava. }\end{array}$ \\
\hline 14 & $\begin{array}{l}\text { Cum quis in ius succedit alterius, } \\
\text { iustam ignorantiae causam censetur } \\
\text { habere. }\end{array}$ & $\begin{array}{l}\text { Kad netko naslijedi od drugoga } \\
\text { kakvo pravo, smatra se da ima } \\
\text { valjan razlog neznanja (o tom } \\
\text { pravu). }\end{array}$ \\
\hline 15 & $\begin{array}{l}\text { Odia restringi et favores convenit } \\
\text { ampliari. }\end{array}$ & $\begin{array}{l}\text { Mržnje treba ograničavati, a } \\
\text { naklonosti uvećavati (povoljno } \\
\text { treba tumačiti ekstenzivno, a } \\
\text { nepovoljno restriktivno). }\end{array}$ \\
\hline 16 & $\begin{array}{l}\text { Decet concessum a Principe beneficium } \\
\text { esse mansurum. }\end{array}$ & $\begin{array}{l}\text { Pristoji se da povlastica koju je dao } \\
\text { vladar bude trajna. }\end{array}$ \\
\hline
\end{tabular}




\begin{tabular}{|c|c|c|}
\hline 17 & $\begin{array}{l}\text { Indultum a iure beneficium non est } \\
\text { alicui auferendum. }\end{array}$ & $\begin{array}{l}\text { Dopuštenje dano sukladno pravu } \\
\text { ne smije se nikome oduzeti. }\end{array}$ \\
\hline 18 & $\begin{array}{l}\text { Non firmatur tractu temporis, quod de } \\
\text { iure ab initio non subsistit. }\end{array}$ & $\begin{array}{l}\text { Neće tijekom vremena osnažiti } \\
\text { ono što je po pravu od početka } \\
\text { nepostojeće. }\end{array}$ \\
\hline 19 & $\begin{array}{l}\text { Non est sine culpa, qui rei, quae ad } \\
\text { eum non pertinet, se immiscet. }\end{array}$ & $\begin{array}{l}\text { Nije bez krivnje tko se upliće u } \\
\text { stvar koja ga se ne tiče. }\end{array}$ \\
\hline 20 & $\begin{array}{l}\text { Nullus pluribus uti defensionibus } \\
\text { prohibetur. }\end{array}$ & $\begin{array}{l}\text { Nikome nije zabranjeno imati više } \\
\text { branitelja. }\end{array}$ \\
\hline 21 & $\begin{array}{l}\text { Quod semel placuit, amplius displicere } \\
\text { non potest. }\end{array}$ & $\begin{array}{l}\text { Što se jednom svidjelo, ne može } \\
\text { se više ne sviđati (Jednom izvršen } \\
\text { izbor ne može se ponoviti). }\end{array}$ \\
\hline 22 & $\begin{array}{l}\text { Non debet aliquis alterius odio } \\
\text { praegravari. }\end{array}$ & $\begin{array}{l}\text { Nitko ne treba trpjeti zbog nečije } \\
\text { mržnje. }\end{array}$ \\
\hline 23 & $\begin{array}{l}\text { Sine culpa, nisi subsit causa, non est } \\
\text { aliquis puniendus. }\end{array}$ & $\begin{array}{l}\text { Bez krivnje, osim ako ne postoji } \\
\text { poseban razlog, nitko ne može biti } \\
\text { kažnjen. }\end{array}$ \\
\hline 24 & $\begin{array}{l}\text { Quod quis mandato facit iudicis, dolo } \\
\text { facere non videtur, cum habeat parere } \\
\text { necesse. }\end{array}$ & $\begin{array}{l}\text { Što netko učini po nalogu suca, } \\
\text { smatra se da nije prijevarno } \\
\text { (protupravno), jer mu se morao } \\
\text { pokoriti. }\end{array}$ \\
\hline 25 & Mora sua cuilibet est nociva. & $\begin{array}{l}\text { Svakome je štetno njegovo } \\
\text { zakašnjenje. }\end{array}$ \\
\hline 26 & $\begin{array}{l}\text { Ea, quae fiunt a iudice, si ad eius } \\
\text { non spectant officium, viribus non } \\
\text { subsistunt. }\end{array}$ & $\begin{array}{l}\text { Sve ono što učini sudac izvan } \\
\text { svojih ovlasti nema pravnu snagu. }\end{array}$ \\
\hline 27 & $\begin{array}{l}\text { Scienti et consentienti non fit iniuria } \\
\text { neque dolus. }\end{array}$ & $\begin{array}{l}\text { Onomu koji zna i pristaje ne } \\
\text { može se počiniti ni povreda niti } \\
\text { prijevara. }\end{array}$ \\
\hline 28 & $\begin{array}{l}\text { Quae a iure communi exorbitant, } \\
\text { nequaquam ad consequentiam sunt } \\
\text { trahenda. }\end{array}$ & $\begin{array}{l}\text { Ono što izlazi iz okvira općeg } \\
\text { pravila, ne može se proširivati na } \\
\text { druge slučajeve. (Odstupa li kakva } \\
\text { odredba od općeg pravila, tumači } \\
\text { se u najužem opsegu). }\end{array}$ \\
\hline 29 & $\begin{array}{l}\text { Quod omnes tangit, debet ab omnibus } \\
\text { approbari. }\end{array}$ & $\begin{array}{l}\text { Što se tiče svih, svi trebaju i } \\
\text { odobriti. }\end{array}$ \\
\hline 30 & In obscuris minimum est sequendum. & $\begin{array}{l}\text { U dvojbenim stvarima slijedi se } \\
\text { ono što je najmanje (teško, rizično, } \\
\text { teretno). }\end{array}$ \\
\hline 31 & $\begin{array}{l}\text { Eum, qui certus est, certiorari ulterius } \\
\text { non oportet. }\end{array}$ & $\begin{array}{l}\text { Ono što je nesumnjivo utvrđeno, } \\
\text { nepotrebno je dalje utvrđivati. }\end{array}$ \\
\hline
\end{tabular}




\begin{tabular}{|c|c|c|}
\hline 32 & $\begin{array}{l}\text { Non licet actori, quod reo licitum non } \\
\text { existit. }\end{array}$ & $\begin{array}{l}\text { Nije dopušteno tužitelju ono što } \\
\text { nije dopušteno tuženiku. }\end{array}$ \\
\hline 33 & $\begin{array}{l}\text { Mutare consilium quis non potest in } \\
\text { alterius detrimentum. }\end{array}$ & $\begin{array}{l}\text { Nitko se ne može predomisliti na } \\
\text { štetu drugoga. }\end{array}$ \\
\hline 34 & Generi per speciem derogatur. & Posebno ukida opće. \\
\hline 35 & $\begin{array}{l}\text { Plus semper in se continet quod est } \\
\text { minus. }\end{array}$ & $\begin{array}{l}\text { Više uvijek sadrži u sebi ono što je } \\
\text { manje. }\end{array}$ \\
\hline 36 & $\begin{array}{l}\text { Pro possessore habetur, qui dolo desiit } \\
\text { possidere. }\end{array}$ & $\begin{array}{l}\text { Uzima se da je posjednik i onaj tko } \\
\text { je prijevarno napustio posjed. }\end{array}$ \\
\hline 37 & Utile non debet per inutile vitiari. & $\begin{array}{l}\text { Valjano se ne treba kvariti } \\
\text { nevaljanim. }\end{array}$ \\
\hline 38 & $\begin{array}{l}\text { Ex eo non debet quis fructum consequi, } \\
\text { quod nisus extitit impugnare. }\end{array}$ & $\begin{array}{l}\text { Ne smije iz čega izvući korist } \\
\text { onaj tko se tome (istome) ustrajno } \\
\text { protivio. }\end{array}$ \\
\hline 39 & $\begin{array}{l}\text { Cum quid prohibetur, prohibentur } \\
\text { omnia quae sequuntur ex illo. }\end{array}$ & $\begin{array}{l}\text { Kada je nešto zabranjeno, } \\
\text { zabranjeno je i sve ono što iz toga } \\
\text { proistječe. }\end{array}$ \\
\hline 40 & $\begin{array}{l}\text { Pluralis locutio duorum numero est } \\
\text { contenta. }\end{array}$ & $\begin{array}{l}\text { Za izraz množina dostatan je i broj } \\
\text { "dva". }\end{array}$ \\
\hline 41 & $\begin{array}{l}\text { Imputari non debet ei, per quem non } \\
\text { stat, si non faciat, quod per eum fuerat } \\
\text { faciendum. }\end{array}$ & $\begin{array}{l}\text { Ne može se okriviti nekoga da nije } \\
\text { učinio nešto što je trebao ako to } \\
\text { nije spadalo na njega. }\end{array}$ \\
\hline 42 & $\begin{array}{l}\text { Accessorium naturam sequi congruit } \\
\text { principalis. }\end{array}$ & Pripadak slijedi narav glavne stvari. \\
\hline 43 & Qui tacet, consentire videtur. & Tko šuti, smatra se da pristaje. \\
\hline 44 & $\begin{array}{l}\text { Is, qui tacet, non fatetur, sed nec utique } \\
\text { negare videtur. }\end{array}$ & $\begin{array}{l}\text { Onaj tko šuti, ne priznaje, ali } \\
\text { svakako se smatra da ni ne poriče. }\end{array}$ \\
\hline 45 & $\begin{array}{l}\text { Inspicimus in obscuris quod est } \\
\text { verisimilius vel quod plerumque fieri } \\
\text { consuevit. }\end{array}$ & $\begin{array}{l}\text { U dvojbenim stvarima trebamo } \\
\text { ispitati ono što je najvjerojatnije ili } \\
\text { ono što se uobičajeno događa. }\end{array}$ \\
\hline 46 & $\begin{array}{l}\text { Is, qui in ius succedit alterius, eo iure } \\
\text { quo ille uti debebit. }\end{array}$ & $\begin{array}{l}\text { Onaj tko naslijedi pravni položaj } \\
\text { drugoga, treba imati ista prava koja } \\
\text { je taj imao. }\end{array}$ \\
\hline 47 & $\begin{array}{l}\text { Praesumitur ignorantia, ubi scientia } \\
\text { non probatur. }\end{array}$ & $\begin{array}{l}\text { Predmnijeva se neznanje tamo gdje } \\
\text { se znanje ne može dokazati. }\end{array}$ \\
\hline 48 & $\begin{array}{l}\text { Locupletari non debet aliquis cum } \\
\text { alterius iniuria aut iactura. }\end{array}$ & $\begin{array}{l}\text { Nitko se ne smije obogatiti } \\
\text { povredom tuđih prava ili na tuđi } \\
\text { teret. }\end{array}$ \\
\hline 49 & $\begin{array}{l}\text { In poenis benignior est interpretatio } \\
\text { facienda. }\end{array}$ & $\begin{array}{l}\text { U kaznenim stvarima treba } \\
\text { prihvatiti povoljnije (blaže) } \\
\text { tumačenje. }\end{array}$ \\
\hline
\end{tabular}




\begin{tabular}{|c|c|c|}
\hline 50 & $\begin{array}{l}\text { Actus legitimi condicionem non } \\
\text { recipiunt neque diem. }\end{array}$ & $\begin{array}{l}\text { Određenim se poslovima ne može } \\
\text { dodati ni uvjet, ni rok. }\end{array}$ \\
\hline 51 & $\begin{array}{l}\text { Semel Deo dedicatum non est ad usus } \\
\text { humanos ulterius transferendum. }\end{array}$ & $\begin{array}{l}\text { Ono što je jednom posvećeno } \\
\text { Bogu, ne može se više uporabiti u } \\
\text { ljudske (svjetovne) svrhe. }\end{array}$ \\
\hline 52 & $\begin{array}{l}\text { Non praestat impedimentum, quod de } \\
\text { iure non sortitur effectum. }\end{array}$ & $\begin{array}{l}\text { Ne predstavlja zapreku ono iz čega } \\
\text { ne proistječe (nikakva) pravna } \\
\text { posljedica. }\end{array}$ \\
\hline 53 & $\begin{array}{l}\text { Cui licet quod est plus, licet utique quod } \\
\text { est minus. }\end{array}$ & $\begin{array}{l}\text { Kome je dopušteno ono što je više, } \\
\text { svakako mu je dopušteno i ono što } \\
\text { je manje. }\end{array}$ \\
\hline 54 & Qui prior est tempore, potior est iure. & $\begin{array}{l}\text { Tko je raniji u vremenu, jači je u } \\
\text { pravu. }\end{array}$ \\
\hline 55 & $\begin{array}{l}\text { Qui sentit onus, sentire debet } \\
\text { commodum, } \\
\text { et contra. }\end{array}$ & $\begin{array}{l}\text { Tko snosi teret, treba imati i korist } \\
\text { (i obratno). }\end{array}$ \\
\hline 56 & $\begin{array}{l}\text { In re communi potior est condicio } \\
\text { prohibentis. }\end{array}$ & $\begin{array}{l}\text { Kod zajedničke stvari jači je } \\
\text { položaj onog koji zabranjuje. }\end{array}$ \\
\hline 57 & $\begin{array}{l}\text { Contra eum, qui legem dicere potuit } \\
\text { apertius, est interpretatio facienda. }\end{array}$ & $\begin{array}{l}\text { Tumačenje treba usmjeriti protiv } \\
\text { onoga koji je mogao jasnije odrediti } \\
\text { sadržaj (pravnog posla). }\end{array}$ \\
\hline 58 & $\begin{array}{l}\text { Non est obligatorium contra bonos } \\
\text { mores praestitum iuramentum. }\end{array}$ & $\begin{array}{l}\text { Prisega dana protiv dobrih običaja } \\
\text { ne obvezuje. }\end{array}$ \\
\hline 59 & $\begin{array}{l}\text { Dolo facit, qui petit, quod restituere } \\
\text { oportet eundem. }\end{array}$ & $\begin{array}{l}\text { Prijevarno postupa onaj tko } \\
\text { zahtijeva isto ono što će morati } \\
\text { vratiti. }\end{array}$ \\
\hline 60 & $\begin{array}{l}\text { Non est in mora, qui potest exceptione } \\
\text { legitima se tueri. }\end{array}$ & $\begin{array}{l}\text { Nije u zakašnjenju onaj tko } \\
\text { se može braniti zakonitim } \\
\text { prigovorom. }\end{array}$ \\
\hline 61 & $\begin{array}{l}\text { Quod ob gratiam alicuius conceditur, } \\
\text { non est in eius dispendium } \\
\text { retorquendum. }\end{array}$ & $\begin{array}{l}\text { Što se kome daje kao prednost, ne } \\
\text { može mu se obrnuti u nedostatak. }\end{array}$ \\
\hline 62 & $\begin{array}{l}\text { Nullus ex consilio, dummodo } \\
\text { fraudulentum non fuerit, obligatur. }\end{array}$ & $\begin{array}{l}\text { Savjet nikoga ne obvezuje, osim } \\
\text { ako nije prijevaran. }\end{array}$ \\
\hline 63 & $\begin{array}{l}\text { Exceptionem obiiciens non videtur de } \\
\text { intentione adversarii confiteri. }\end{array}$ & $\begin{array}{l}\text { Tko ističe prigovor, smatra se da ne } \\
\text { priznaje zahtjev protivnika. }\end{array}$ \\
\hline 64 & $\begin{array}{l}\text { Quae contra ius fiunt, debent utique } \\
\text { pro infectis haberi. }\end{array}$ & $\begin{array}{l}\text { Što je učinjeno suprotno pravu, } \\
\text { treba se svakako uzeti kao } \\
\text { nevaljano. }\end{array}$ \\
\hline 65 & $\begin{array}{l}\text { In pari delicto vel causa potior est } \\
\text { condicio possidentis. }\end{array}$ & $\begin{array}{l}\text { U jednakoj situaciji povoljniji je } \\
\text { položaj posjednika. }\end{array}$ \\
\hline
\end{tabular}




\begin{tabular}{|c|c|c|}
\hline 66 & $\begin{array}{l}\text { Cum non stat per eum ad quem } \\
\text { pertinet, quominus condicio impleatur, } \\
\text { haberi debet perinde, ac si impleta } \\
\text { fuisset. }\end{array}$ & $\begin{array}{l}\text { Kada onaj kojem odgovara } \\
\text { ispunjenje uvjeta nije odgovoran za } \\
\text { njegovo neispunjenje, treba se uzeti } \\
\text { da je uvjet ispunjen. }\end{array}$ \\
\hline 67 & $\begin{array}{l}\text { Quod alicui suo non licet nomine, nec } \\
\text { alieno licebit. }\end{array}$ & $\begin{array}{l}\text { Što nekome nije dopušteno (učiniti) } \\
\text { u svoje ime, ne može mu biti } \\
\text { dopušteno (učiniti) ni u tuđe (ime). }\end{array}$ \\
\hline 68 & $\begin{array}{l}\text { Potest quis per alium, quod potest facere } \\
\text { per se ipsum. }\end{array}$ & $\begin{array}{l}\text { Može se učiniti preko drugoga } \\
\text { (npr. zastupnika) ono što se može } \\
\text { učiniti i samostalno. }\end{array}$ \\
\hline 69 & $\begin{array}{l}\text { In malis promissis fidem non expedit } \\
\text { observari. }\end{array}$ & $\begin{array}{l}\text { Kod zlih (nepoštenih, nemoralnih) } \\
\text { obećanja nije se potrebno držati } \\
\text { dane riječi. }\end{array}$ \\
\hline 70 & $\begin{array}{l}\text { In alternativis debitoris est electio, et } \\
\text { sufficit alterum adimpleri. }\end{array}$ & $\begin{array}{l}\text { Kod alternativnih obveza izbor } \\
\text { ima dužnik te dostaje ispuniti koju } \\
\text { od njih. }\end{array}$ \\
\hline 71 & $\begin{array}{l}\text { Qui ad agendum admittitur, est ad } \\
\text { excipiendum multo magis admittendus. }\end{array}$ & $\begin{array}{l}\text { Tko ima pravo podnijeti tužbu, } \\
\text { tim više može istaknuti prigovor. }\end{array}$ \\
\hline 72 & $\begin{array}{l}\text { Qui facit per alium, est perinde, ac si } \\
\text { faciat per se ipsum. }\end{array}$ & $\begin{array}{l}\text { Sto netko čini preko drugoga, isto } \\
\text { je kao da je i sam to učinio. }\end{array}$ \\
\hline 73 & $\begin{array}{l}\text { Factum legitime retractari non debet, } \\
\text { licet causa postea eveniat, a quo non } \\
\text { potuit inchoari. }\end{array}$ & $\begin{array}{l}\text { Ono što je učinjeno kao zakonito } \\
\text { neće postati nevaljano ako se } \\
\text { naknadno pojavi razlog koji bi } \\
\text { onemogućio taj čin. }\end{array}$ \\
\hline 74 & $\begin{array}{l}\text { Quod alicui gratiose conceditur, trahi } \\
\text { non debet ab aliis in exemplum. }\end{array}$ & $\begin{array}{l}\text { Milost koju se nekome dodjeljuje } \\
\text { drugi ne mogu isticati kao primjer } \\
\text { (tj. tražiti analogijom proširenje te } \\
\text { iznimke). }\end{array}$ \\
\hline 75 & $\begin{array}{l}\text { Frustra sibi fidem quis postulat ab } \\
\text { eo servari, cui fidem a se praestitam } \\
\text { servare recusat. }\end{array}$ & $\begin{array}{l}\text { Uzalud traži držati se zadane riječi } \\
\text { onaj tko odbija držati se riječi koju } \\
\text { je sam (drugome) dao. }\end{array}$ \\
\hline 76 & $\begin{array}{l}\text { Delictum personae non debet in } \\
\text { detrimentum Ecclesiae redundare. }\end{array}$ & $\begin{array}{l}\text { Protupravno djelo pojedinca ne } \\
\text { smije ići na štetu Crkve (kao } \\
\text { zajednice). }\end{array}$ \\
\hline 77 & $\begin{array}{l}\text { Rationi congruit, ut succedat in onere, } \\
\text { qui substituitur in honore. }\end{array}$ & $\begin{array}{l}\text { U skladu je s razumom da onaj } \\
\text { tko nekoga naslijedi u časti, istoga } \\
\text { naslijedi i u teretu (obvezi). }\end{array}$ \\
\hline 78 & $\begin{array}{l}\text { In argumentum trahi nequeunt, quae } \\
\text { propter necessitatem aliquando sunt } \\
\text { concessa. }\end{array}$ & $\begin{array}{l}\text { Ne može se isticati kao ogledno } \\
\text { nešto što je jednom (iznimno) bilo } \\
\text { dopušteno zbog nužde. }\end{array}$ \\
\hline 79 & $\begin{array}{l}\text { Nemo potest plus iuris transferre } \\
\text { in alium, quam sibi ipsi competere } \\
\text { dignoscatur. }\end{array}$ & $\begin{array}{l}\text { Poznato je da nitko ne može na } \\
\text { drugoga prenijeti više prava nego } \\
\text { što sam ima. }\end{array}$ \\
\hline
\end{tabular}




\begin{tabular}{|c|c|c|}
\hline 80 & $\begin{array}{l}\text { In toto partem non est dubium } \\
\text { contineri. }\end{array}$ & $\begin{array}{l}\text { Nema dvojbe da je u cjelini } \\
\text { sadržan i dio. }\end{array}$ \\
\hline 81 & $\begin{array}{l}\text { In generali concessione non veniunt } \\
\text { ea, quae quis non esset verosimiliter in } \\
\text { specie concessurus. }\end{array}$ & $\begin{array}{l}\text { U opće dopuštenje nije uključeno } \\
\text { ono što se najvjerojatnije ne bi } \\
\text { dopustilo u posebnom slučaju. }\end{array}$ \\
\hline 82 & $\begin{array}{l}\text { Qui contra iura mercatur, bonam fidem } \\
\text { praesumitur non habere. }\end{array}$ & $\begin{array}{l}\text { Tko trguje suprotno pravu, } \\
\text { predmnijeva se da nije u dobroj vjeri. }\end{array}$ \\
\hline 83 & $\begin{array}{l}\text { Bona fides non patitur, ut semel } \\
\text { exactum iterum exigatur. }\end{array}$ & $\begin{array}{l}\text { Dobra vjera ne trpi iznova tražiti } \\
\text { ono što se već jednom tražilo. }\end{array}$ \\
\hline 84 & $\begin{array}{l}\text { Cum quid una via prohibetur alicui, ad } \\
\text { id alia non debet admitti. }\end{array}$ & $\begin{array}{l}\text { Kad je nekome nešto zabranjeno } \\
\text { na jedan način, ne treba mu to } \\
\text { dopustiti na drugi. }\end{array}$ \\
\hline 85 & $\begin{array}{l}\text { Contractus ex conventione legem } \\
\text { accipere dignoscuntur. }\end{array}$ & $\begin{array}{l}\text { Poznato je da ugovori dobivaju } \\
\text { snagu zakona iz sporazuma } \\
\text { (stranaka). }\end{array}$ \\
\hline 86 & $\begin{array}{l}\text { Damnum quod quis sua culpa sentit, } \\
\text { sibi debet, non aliis imputare. }\end{array}$ & $\begin{array}{l}\text { Štetu koju netko pretrpi svojom } \\
\text { krivnjom treba pripisati sebi } \\
\text { samom, a ne drugima. }\end{array}$ \\
\hline 87 & $\begin{array}{l}\text { Infamibus portae non pateant } \\
\text { dignitatum. }\end{array}$ & $\begin{array}{l}\text { Vrata časti (javnih službi) ne smiju } \\
\text { biti otvorena za nečasne. }\end{array}$ \\
\hline 88 & $\begin{array}{l}\text { Certum est, quod is committit in legem, } \\
\text { qui legis verba complectens contra legis } \\
\text { nititur voluntatem. }\end{array}$ & $\begin{array}{l}\text { Sigurno je da je povrijedio zakon } \\
\text { onaj tko, držeći se slova zakona, } \\
\text { ide protiv njegova duha. }\end{array}$ \\
\hline
\end{tabular}

\section{LITERATURA}

Andrassy, J., Medunarodno pravo, Zagreb, 1990.

Archi, G. G., "Ait Praetor: 'Pacta conventa servabo", u: Harder, M., Thielmann, G. (eds.), De iustitia et iure. Festgabe für Ulrich von Lübtow zum 80. Geburtstag, Berlin, 1980., str. 373-403.

Berljak, M., Katedra kanonskoga prava Katoličkoga bogoslovnog fakulteta Sveučilišta u Zagrebu, Tkalčić. Godišnjak Društva za povjesnicu Zagrebačke nadbiskupije, 9 (2005), str. 411-442.

Berljak, M., Zakonik crkvenog prava, uređen po odredbi pape Pija X., proglašen po nalogu pape Benedikta XV. (1917.). Dr. Josip Pazman (1863.-1925.), Zagreb/ Rim, 2014.

Bojanić, I., Mrčela, M., Koncepcija krivnje u novom Kaznenom zakonu, Hrvatski ljetopis za kazneno pravo i praksu, 19 (2012), br. 2., Zagreb, 2012., str. 389-407.

Bratković, M., Što je važno pitanje u reviziji?, Zbornik Pravnog fakulteta u Zagrebu, 68 (2018), br. 5-6, str. 853-880. 
Brkan, J., Neke razlike u Zakonicima latinske Crkve i istočnih katoličkih crkava, Služba Božja 54 (2014), br. 1, str. 5-34.

Brkan, J., Opće odredbe Zakonika kanonskog prava, Makarska, 1997.

Brkan, J., Ugovori i napose otudenje (kan. 1290-1298), Služba Božja 45 (2004), br. 2., str. 8-37.

Ceccarelli Morolli, D., "Fragmenta Iuris Romani-Byzantini” nel Codex Canonum Ecclesiarum Orientalium: note per un primo studio, Iura Orientalia, 1 (2005), str. 77-87.

Codex Canonum Ecclesiarum Orientalium fontium annotatione auctus/Zakonik kanona istočnih Crkava s izvorima, Zagreb, 1996.

Codex Iuris Canonici fontium annotatione auctus MDCCCCXVII/Kodeks kanonskog prava s izvorima 1917. (preveo Franjo Herman), Zagreb, 2007.

Codex Iuris Canonici fontium annotatione auctus/Zakonik kanonskog prava s izvorima, Zagreb, 1996.

Condorelli, O., Roumy, F., Schmoeckel, M., Mausen Y., von Mayenburg, D., Der Einfluss der Kanonistik auf die europäische Rechtskultur: Bd. 1: Zivil- und Zivilprozessrecht; Bd. 2: Öffentliches Recht; Bd. 3: Straf- und Strafprozessrecht; Bd. 4: Prozessrecht; Bd. 5: Das Recht der Wirtschaft, Wien/Köln/ Weimar, 2009-2016.

Domingo, R. et al., Principios de derecho global. 1000 reglas y aforismos jurídicos comentados, Navarra, 2006.

Đurđević, Z., Pravna osoba kao okrivljenik: temeljna prava i predstavljanje, Hrvatski ljetopis za kazneno pravo i praksu, 12 (2005), br. 2., str. 739-762.

Eterović, N., Ugovori između Svete Stolice i Republike Hrvatske (povijest nastanka i komentar), Zagreb, 2001.

Eterović, N., Ugovori između Svete Stolice i Republike Hrvatske, Crkva u svijetu, 32 (1997), br. 2, str. 181-186.

Gaudemet, J., Les sources du droit canonique (VIII ${ }^{e}$ XX $X^{e}$ siècle), Paris, 1993.

Gavella, N. et al., Hrvatsko građanskopravno uređenje i kontinentalnoeuropski pravni krug, Zagreb, 1994.

Gavella, N., Belaj, V., Nasljedno pravo, Zagreb, 2008.

Gavella, N., Građansko pravo u Hrvatskoj i kontinentalno-europski pravni krug - u povodu 140. godišnjice stupanja na snagu OGZ u Hrvatskoj, Zbornik Pravnog fakulteta u Zagrebu, 43 (1993), str. 335-375.

Hamza, G., Die Entwicklung des Privatrechts auf römischrechtlicher Grundlage unter besonderer Berücksichtigung der Rechtsentwicklung in Deutschland, Österreich, der Schweiz und Ungarn, Budapest, 2002. 
Ivanišević, G., Marčanska unija 16I1. i Križevačka eparhija 1777. Ljetopis i pojmovnik, Zagreb, 2018.

Jakulj, I., Pravni položaj Katoličke Crkve u Republici Hrvatskoj: od totalitarizma do demokracije, Crkva u svijetu, 50 (2015), br. 3, str. 478-513.

Klarić, P., Vedriš, M., Građansko pravo, Zagreb, 2006.

Knütel, R., Ius commune und Römisches Recht vor Gerichten der Europäischen Union, Juristische Schulung, Heft 9, 1996, str. 768-778.

Kranjc, J., Latinski pravni reki, Ljubljana, 1998.

Krapac, D., Kazneno procesno pravo, Zagreb, 2003.

Landau, P., Der Einfluß des kanonischen Rechts auf die europäische Rechtskultur, u: Schulze, R. (ed.), Europäische Rechts- und Verfassungsgeschichte. Ergebnisse und Perspektiven der Forschung, Berlin, 1991, str. 39-57.

Landau, P., Pacta sunt servanda. Zu den kanonistischen Grundlagen der Privatautonomie, u: Ascheri, M. et al., "Ins Wasser geworfen und Ozeane durchquert". Festschrift für Knut Wolfgang Nörr, Köln/Weimar/Wien, 2003, str. 457-474.

Lanović, M., Privatno pravo Tripartita, Zagreb, 1929.

Liebs, D., Lateinische Rechtsregeln und Rechtssprichwörter, München, 1991.

Majstorović, I., Zaruke i miraz kao neregulirani instituti suvremenog hrvatskog obiteljskog prava, Zbornik Pravnog fakulteta u Zagrebu, 55 (2005), br. 3-4, str. 733-774.

Milić, I., Pregled madžarskog privatnog prava u poredjenju sa austrijskim građanskim zakonikom, Subotica, 1921.

Milotić, I., Zaruke u europskoj pravnoj tradiciji do XIX. stoljeća i njihovo uređenje na hrvatskom pravnom prostoru, u: Šalković, J. (ur.), Zaručništvo i priprava za ženidbu, Zagreb, 2015, str. 47-74.

Mora, M., Über den Unterricht des römischen Rechtes in Ungarn in den letzten hundert Jahren, Revue internationale des droit de l'antiquité (RIDA), 11 (1964), str. 409-432.

Mosconi, M., Sede vacante nihil innovetur: i limiti all'esercizio dell'autorità nella condizione di vacanza della sede, Quaderni di diritto ecclesiale, 17 (2004), str. 146-175.

Nikodem, K., Zrinščak, S., Croatia's religious story: The coexistence of institutionalized and individual religiosity, u: Pollack, D., Müller, O., Pickel, G. (eds.), The social significance of religion in the enlarged Europe, Farnham/Burlington, 2012, str. 207-227

Petrak, M., »In nostro territorio matrimonii promissio (sponsalia) sensu iuridico non amplius dantur«? Kratke napomene o kanonskom uređenju zaruka u Hrvatskoj (Kan. 1062), u: Šalković, J. (ur.), Zaručništvo i priprava za ženidbu, Zagreb, 2015, str. 31-45. 
Petrak, M., Rimsko pravo kao pozitivno pravo u Republici Hrvatskoj. Prilog tumačenju Zakona o načinu primjene pravnih propisa donesenih prije 6. travnja 1941. godine, Hrvatska pravna revija, 6 (2006), str. 1-11.

Petrak, M., Traditio iuridica, vol. I: Regulae iuris, Zagreb, 2010.

Petrak, M., Utrumque ius i suvremeni pravni sustavi, u: Škalabrin, N. (ur.), Franjo Herman i Kodeks iz 1917. Suum cuique tribuere, Đakovo, 2008., str. 137-149.

Pree, H., Traditio Canonica. The Norm of Interpretation of Canon 6 sec. 2 of the C.I.C., Ius Canonicum, 35 (1995), str. 423-446.

Pree, H., Generalia Iuris Principia Im CIC/1983 und Ihre Bedeutung für das Kanonische Recht, Archiv für katholisches Kirchenrecht, 172 (2003), no. 1, str. 38-57.

Radovčić, V., Pokušaj kodifikacije građanskog prava u staroj Jugoslaviji ("Predosnova građanskog zakonika za Kraljevinu Jugoslaviju”), Radovi Instituta za hrvatsku povijest, 7 (1975), str. 249-307.

Rehak, M., Regulae iuris und allgemeine Rechtsprinzipien im kanonischen Recht, u: Schüller, T., Neumann, T. (eds.), Kirchenrecht im Dialog. Tagungsband zur Tagung des Instituts für kanonisches Recht, Fulda, 18.-20. Februar 2019, Berlin, 2020, str. 43-72.

Rogić, I., Kanonsko pravo I. Prva knjiga Kodeksa. Opća pravila (Normae generales), Đakovo, 1939.

Scholler, H. (ed.), Die Bedeutung des kanonischen Rechts für die Entwicklung einheitlicher Rechtsprinzipien, Baden-Baden, 1996.

Stein, P., The Digest Title, De diversis regulis iuris antiqui and the General Principles of Law, u: Newman, R. A. (ed.), Essays in Jurisprudence in Honor of Roscoe Pound, Indianopolis/New York, 1962, str. 1-20.

Stipković, Z. (ur.), Zakon o osnovnim vlasničkopravnim odnosima, Zagreb, 1991.

Škalabrin, N., Ugovori i napose otudenje (kann. 1290-1298), Bogoslovska smotra, 76 (2006), br. 1., str. 137-199.

Škalabrin, N., Uvod u kanonsko pravo, Đakovo, 1994.

Triva, S., Dika, M., Građansko parnično procesno pravo, Zagreb, 2004.

Wacke, A., Sprichwörtliche Rechtsprinzipien und europäische Rechtsangleichung, Orbis iuris romani, 5 (1999), str. 174-213.

Wolter, U., Ius canonicum in iure civili. Studien zur Rechtsquellenlehre in der neueren Privatrechtsgeschichte, Köln/Wien, 1975.

Zec, S., Pravni temelji prisutnosti i djelovanja Crkve u javnosti u Republici Hrvatskoj, Riječki teološki časopis, 36 (2011), br. 2, str. 387-412.

Zimmermann, R., The Law of Obligations, Roman Foundations of the Civilian Tradition, Oxford, 1996.

Žuvela, M., Vlasničkopravni odnosi, Zagreb, 2009. 
Summary

\section{Marko Petrak*}

\section{CANON LAW AND THE CROATIAN LEGAL SYSTEM (I) LEGAL SOURCES AND LEGAL PRINCIPLES}

The intention of the article is to analyze the issue of canon law of the Catholic Church as a source of law in the Croatian legal system. After a brief analysis of the most important sources of canon law, further analysis focuses on the meaning and function of the principles of canon law in regards to the Croatian legal system. In the analysis, the author concentrates in particular on legal maxims (regulae iuris) as an undoubtedly extremely important traditional form of legal rules, which in many cases embody basic legal principles.

In the central part of the paper, the applicability of regulae iuris canonici as a direct source of contemporary Croatian law, especially in the sense of legal principles, is analysed. The author concludes that their application is possible under the conditions provided by the Act on the Application of Legal Rules Enacted Before 6 April 1941, primarily due to the fact that traditional regulae iuris canonici, i.e. 99 canon law maximes contained in the Decretales of Pope Gregory IX (1234) and Liber Sextus of Pope Bonifacius VIII (1298), were law in force on the said date in the Croatian territories belonging to the ex-Hungarian legal area.

Taking this into account, the concluding part of the paper examines the application of concrete regulae iuris canonici as legal principles in the Croatian judicial practice (nulla poena sine culpa; ignorantia iuris non excusat; accessorium sequitur principale; qui tacet, consentire videtur; prior tempore, potior iure). Although regulae iuris canonici have, in the formal sense, merely the status of a subsidiary source of law, in terms of their content, they can be of fundamental importance for the contemporary Croatian legal system, considering that a series of these rules contain the basic legal principles on which a range of the most important institutes of Croatian law are founded. Therefore, the appendix to this article includes the first complete Croatian translation of these canon law maxims, so that legal doctrine and especially judicial practice can be better acquainted with these timeless legal principles.

Proceeding from the fact that the aforementioned canon law principles formulated as Latin legal maxims represent an important traditional and concise expression of the very essence of the European legal tradition and culture, the author concludes that a possible

\footnotetext{
* Marko Petrak, Ph. D., Professor, Faculty of Law, University of Zagreb, Trg Republike Hrvatske 14, 10000 Zagreb, Croatia; marko.petrak@pravo.hr;

ORCID ID: orcid.org/0000-0003-0920-8361
} 
wider scope of application of the regulae iuris canonici in Croatian judicial practice would not represent merely a nostalgic quest for the hidden treasure of the European legal tradition, but a part of a long-term creative effort at the Europeanization of contemporary national legal systems on the firm foundations of the common legal culture.

Keywords: canon law; Croatian law; legal sources; legal principles; regulae iuris 